\title{
Ultraphytoplankton basin-scale distribution in the eastern Mediterranean Sea in winter: link to hydrodynamism and nutrients
}

\author{
M. Denis ${ }^{1}$, M. Thyssen ${ }^{1}$, V. Martin ${ }^{1}$, B. Manca ${ }^{2}$, and F. Vidussi ${ }^{3, *}$ \\ ${ }^{1}$ Laboratoire de Microbiologie, Géochimie et Ecologie Marines, Université de la Méditerranée, CNRS UMR 6117, 163 \\ avenue de Luminy, Case 901, 13288 Marseille cedex 9, France \\ ${ }^{2}$ Istituto Nazionale di Oceanografia e Geofisica Sperimentale - OGS, Borgo Grotta Gigante, 42/c, 34010 Sgonico (Trieste), \\ Italy \\ ${ }^{3}$ Laboratoire d'Océanographie de Villefranche, CNRS UMR 7093, Université de Paris VI, quai de la Darse, B.P. 28,06234 \\ Villefranche-sur-mer cedex, France \\ * present address: Ecosystèmes lagunaires, CNRS, UMR 5119, Université Montpellier II, CP 093, Place Bataillon, 34095 \\ Montpellier cedex 5, France
}

Received: 12 May 2009 - Published in Biogeosciences Discuss.: 13 July 2009

Revised: 22 June 2010 - Accepted: 4 July 2010 - Published: 20 July 2010

\begin{abstract}
The basin-scale distribution of ultraphytoplankton $(<10 \mu \mathrm{m})$ was determined in the upper $200 \mathrm{~m}$ of the eastern Mediterranean Sea during the winter season. Four clusters were resolved by flow cytometry on the basis of their optical properties and identified as Synechococcus, Prochlorococcus, pico- $(<3 \mu \mathrm{m})$ and nanoeukaryotes $(3-10 \mu \mathrm{m})$. Synechococcus was the most abundant population (maximum abundance of about 37000 cells cm $\mathrm{cm}^{-3}$ ) and contributed up to $67.7 \%$ to the overall ultraphytoplanktonic carbon biomass, whereas the contribution of Prochlorococcus never exceeded $6.5 \%$. The maximum integrated carbon biomass was 1763 , 453, 58 and $571 \mathrm{mg} \mathrm{C} \mathrm{m}^{-2}$ for nanoeukaryotes, picoeukaryotes, Prochlorococcus and Synechococcus respectively. Water mass properties were analyzed on the basis of temperature and salinity distributions in order to account for the general circulation and locate the main hydrodynamic structures (fronts, gyres, transition between western and eastern basins). The effect of the main hydrodynamic structures and nutrients on the ultraphytoplankton distribution was investigated. No positive correlation between nutrients and phytoplankton could be established when considering large scales. However, below $50 \mathrm{~m}$ depth, nutrient ratios between particular stations were correlated to corresponding density ratios. In contrast, significant relationships were found be-
\end{abstract}

Correspondence to: $\mathrm{M}$. Denis

(michel.denis@univmed.fr) tween Synechococcus abundance and density, resulting from the impact of a gyre in southern Adriatic basin and a thermohaline front in the Ionian basin. A significant relationship was also found between picoeukaryotes and salinity in the comparison of western and eastern Mediterranean Sea.

\section{Introduction}

Hydrodynamism in the oceans is known to affect phytoplankton distribution. In particular, meso-scale hydrodynamic structures such as fronts, eddies and gyres control the biomass and primary production (McGillicuddy et al., 1998 ) as well as phytoplankton composition (e.g. Rodriguez et al., 2001; Vidussi et al., 2001). Hydrodynamic structures and circulation can influence directly via vertical motion the phytoplankton size structure (Rodriguez et al., 2001). At the same time hydrodynamic structures drive nutrients or modify the light environment and thus indirectly control phytoplankton biomass and composition (Vidussi et al., 2001). The Mediterranean Sea is an ideal region to study physical-biological relationships as different hydrodynamic structures (mesoscale of 10-100 km) occur at relative small scales which can be simultaneously sampled for physical and biological parameters (Claustre et al., 1994; Rodriguez et al., 2001; Vidussi et al., 2001).

Published by Copernicus Publications on behalf of the European Geosciences Union. 
The general Mediterranean circulation is characterized by an inflow of Atlantic Water (AW) at surface and a non return westward deeper flow of the dominant water mass of the Mediterranean Sea, the Levantine Intermediate Water (LIW), into the Atlantic Ocean (Wüst, 1961). As a consequence the Mediterranean Sea is potentially oligotrophic because of the inflow of generally nutrient poor Atlantic surface waters. However, the LIW is known to play an important role in transporting inorganic nutrients around the basin and further on in the Atlantic Ocean (Béthoux, 1979). In fact the LIW affects wintertime dense water formation processes both in the eastern and western basin (Schlitzer et al., 1991; Leaman and Schott, 1991), creating conditions of vertical transfer of nutrient-rich intermediate/deep waters close to the surface for the biological consumption. This is the case for example of the north western Mediterranean Sea where deep convection occurs during winter followed by spring phytoplankton bloom and further by oligotrophy in summer (Marty et al., 2002). At the same time, in the eastern Mediterranean Sea the thermohaline circulation and physical processes establish conditions of low nutrient concentration and low primary production (Azov, 1986; Psara et al., 2000; Tselepides et al., 2000). Thus the Mediterranean Sea is considered as ultraoligotrophic or mesotrophic, depending on the studied area and the season (Berman et al., 1984; Minas et al., 1988; Conan et al., 1998, Krom et al., 2003, 2005). However, among the different Mediterranean Sea regions, the eastern Mediterranean Sea is by far the most oligotrophic region. The general circulation of the eastern Mediterranean Sea has been intensively investigated by the POEM group (1992), which provided evidence of different scales, dynamics and variabilities. Four main regions may be distinguished, i.e. the Adriatic, the Ionian, the Aegean and the Levantine basins, which exhibit different hydrodynamic regimes and processes that have been revealed important for biological and chemical dynamics. Superimposed to the basin-wide thermohaline cell circulation at surface, permanent and/or recurrent subbasin scale gyres exist. These gyres isolate water masses and therefore, they have a large impact on phytoplankton development, such as stimulating it by upward inflows of nutrients.

In the eastern Mediterranean Sea, nutrient concentration and primary production can be very low (Azov, 1986; Bonin et al., 1989), as in the Cretan basin (Psara et al., 2000; Tselepides et al., 2000), thus several extremely nutrient-poor areas of the eastern Mediterraean Sea are ultra-oligotrophic (Krom et al., 2003, 2005; Thingstad et al., 2005). In addition, phosphorus limitation of phytoplankton and bacteria growth was suggested by Berland et al. (1980) and this was confirmed by several studies (Krom et al., 1991; Vaulot et al., 1996; Zohary and Robarts 1998; van Wambeke et al., 2002; see also a review in Krom et al., 2003). A recent lagrangian in situ $\mathrm{P}$-addition experiment carried out in an ultra-oligotrophic region of the eastern Mediterranean Sea (Krom et al., 2005) showed that bacteria was convention- ally P-limited and phytoplankton was $\mathrm{N}$ and P-co limited (Thingstad et al., 2005; Zohary et al., 2005). In oligotrophic waters, a number of studies have shown that ultraphytoplankton $(<10 \mu \mathrm{m})$ makes the most abundant fraction of phytoplankton and that it plays a major role in the overall primary production (Li et al., 1993; Platt et al., 1983; Yacobi et al., 1995; Psarra et al., 2000; Vidussi et al., 2001; see also the recent review by Siokou-Frangou et al., 2010). For instance, over $85 \%$ of chlorophyll $a$ in the eastern basin belong to the $<10 \mu \mathrm{m}$ size fraction (Li et al., 1993). This autotrophic ultraphytoplankton is mainly composed of cyanobacteria, with dominance of Synechococcus over Prochlorococcus (Waterbury et al., 1986; Martin, 1997; Denis et al., 2000; Casotti et al., 2003; Psarra et al., 2005) and of eukaryotes belonging to the group of chlorophyceae, prasinophyceae and prymnesiophyceae (Vidussi et al., 2001; Psarra et al., 2005).

In this oligotrophic region the hydrodynamic structures may induce nutrient enrichments and stimulate biological activity with respect to surrounding areas. Consequently, they may play a significant role in the development of phytoplankton and largely affect the distribution and structure of ultraphytoplankton in the eastern Mediterranean Sea (Casotti et al., 2003). The phytoplankton distribution in the eastern Mediterranean Sea is poorly documented and very fragmented (Li et al., 1993; Yacobi et al., 1995; Magazzu and Decembrini 1995, Psarra et al., 2005; see also Siokou-Frangou et al., 2010).

In the present study, we report the first basin-scale distribution of ultraphytoplanktonic cells $(<10 \mu \mathrm{m})$ determined by flow cytometry over most of the eastern Mediterranean Sea during winter (January 1995). We further analysed this distribution to determine how it could be relatively affected by hydrological structures (gyre, thermohaline front, water masses) and nutrient availability. Results show that hydrology can preferentially affect large-scale phytoplankton distribution.

\section{Materials and methods}

\subsection{Study area and sampling}

Data were collected during the basin-wide R/V METEOR cruise M31/1 (30 December 1994 to 5 February 1995), conducted in the frame of the POEM/BC (Physical Oceanography of the eastern Mediterranean Sea - Biology, Chemistry) and the EU/MAST-MTP (Marine Science and TechnologyMediterranean Targeted Project) of the European Union programme.

The hydrographic work was conducted over a series of 77 full-depth hydrological stations (Fig. 1), while the vertical distribution of ultraphytoplankton in the upper $200 \mathrm{~m}$ was determined at selected 47 stations, 4 in the western and 43 in the eastern Mediterranean Sea, (Fig. 1), lowering a SeaBird-911 Plus conductivity-temperature-depth profiler 


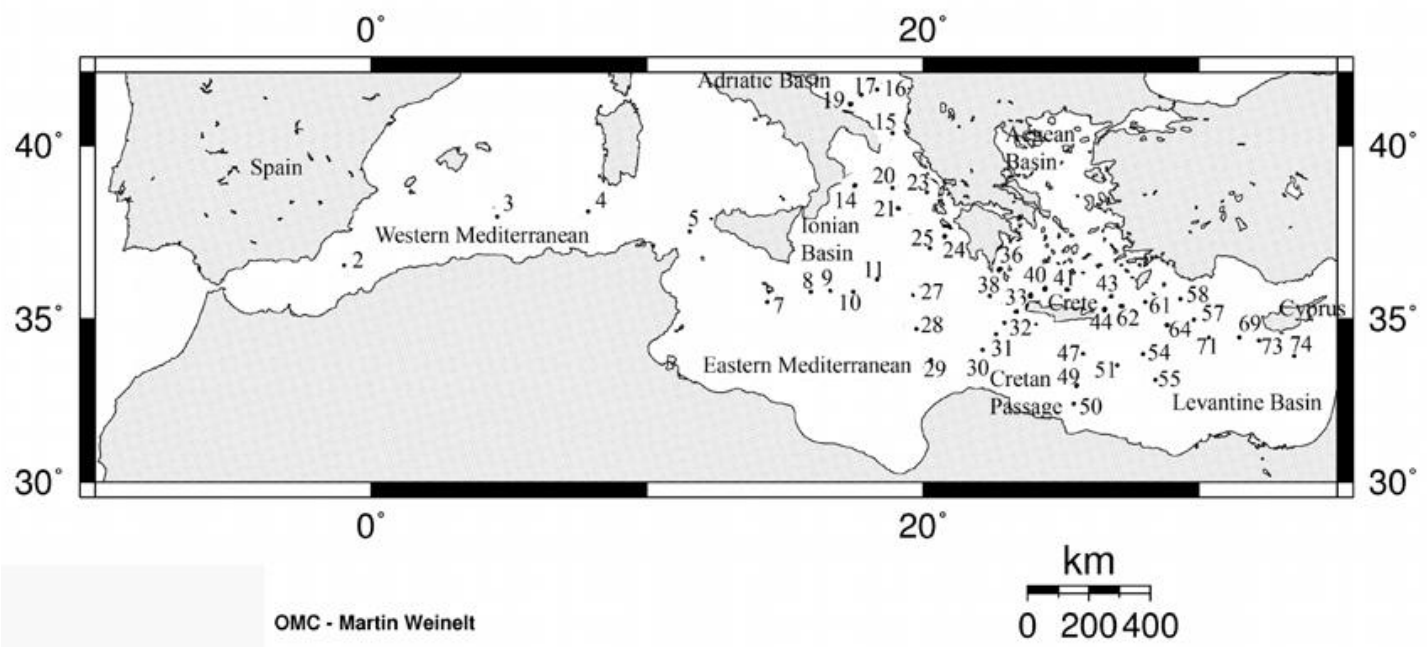

Fig. 1. Location of the stations samples for flow cytometry during the METEOR cruise M31/1 (30 December 1994 to 5 February 1995 ) conducted in the Mediterranean Sea in the frame of the POEM/BC (Physical Oceanography of the eastern Mediterranean Sea - Biology, Chemistry) and the EU/MAST-MTP (Marine Science and Technology-Mediterranean Targeted Project) of the European Union program.

(CTD), equipped with a Sea Teach fluorometer, an oxygen sensor and a rosette water sampler of 24 Niskin bottles of $10 \mathrm{dm}^{3}$. The seawater samples were collected during the upcast at selected depths between 0 to $200 \mathrm{~m}$, according to the most important features displayed by the fluorometer profiles during the down-cast. Four vertical profiles were analyzed in the western Mediterranean Sea for the sake of comparison.

\subsection{Hydrography}

The temperature and salinity data were continuously checked against independent measurements to a precision of \pm 0.002 performed by digital reversing thermometers and water sample analyses on board using an AUTOSAL Guildline bench salinometer. The overall discrepancies were typically less than \pm 0.005 units. Through the text, the temperature is given as potential temperature $(\theta)$, the salinity is reported to the practical salinity scale and the density as potential density excess $(\sigma \theta)$.

The horizontal maps of the hydrographic fields were constructed by extracting temperature, salinity and density values in the upper $10 \mathrm{~m}$ and averaging them on the vertical. The data were objectively analysed on a regular grid of $1 / 4^{\circ}$ using an isotropic correlation function (Carter and Robinson, 1987) after detrending by a first order polynomial function. The derived fields were not represented in the maps where the errors exceeded $60 \%$ (see supplementary material).

The mixed layer depth (MLD) is the depth at which the potential density $(\sigma \theta)$ varies by a given threshold value $(\Delta \sigma \theta)$ from that at a near-surface reference depth $\left(Z_{\text {ref }}\right)$. After a visual inspection of the CTD profiles in the different regions analyzed, the $Z_{\text {ref }}$ was set at $2 \mathrm{~m}$ to avoid a large part of density gradient due to the diurnal variability and a $\Delta \sigma \theta$ of
$0.02 \mathrm{~kg} \mathrm{~m}^{-3}$ seems a good compromise. The MLD calculated with a threshold value of $\Delta \sigma \theta=0.05 \mathrm{~kg} \mathrm{~m}^{-3}$ often fell within the seasonal thermocline rather than at its top. However in some stations the mixed layer was characterised by a shallower actively mixing layer and an underlying layer that had been mixed within the last few weeks or months. In these circumstances the threshold value of $0.05 \mathrm{~kg} \mathrm{~m}^{-3}$ was chosen.

\subsection{Flow cytometry}

The seawater samples were collected at 12 different depths between 0 and $200 \mathrm{~m}$, fired during the up-cast at selected depths according to the most important features displayed by the fluorometer profiles during the down-cast. For flow cytometric analysis, seawater samples $\left(100\right.$ to $\left.150 \mathrm{~cm}^{3}\right)$ from Niskin bottles were prefiltred on $100 \mu \mathrm{m}$ mesh size net to prevent clogging of the flow cell and homogenized. Subsamples of $5 \mathrm{~cm}^{3}$ were fixed with $2 \%$ (final concentration) paraformaldehyde (Trousselier et al., 1995; see also Vaulot et al., 1989) and stored in liquid nitrogen up to analysis in the laboratory, shortly after the cruise (Martin, 1997).

Single cell analysis was run with a CYTORON ABSOLUTE (ORTHO Diagnostic Systems) flow cytometer, equiped with an air-cooled argon laser (excitation wavelength at $488 \mathrm{~nm}$ ). Each cell was characterized by 5 optical parameters: two scatter parameters, namely forward angle scatter (related to the particle size) and right angle scatter (related to cell structure and shape), and three fluorescence parameters related to emissions in the red $(>620 \mathrm{~nm})$, orange $(565-592 \mathrm{~nm})$ and green $(515-530 \mathrm{~nm})$ wavelength ranges.

Just before analysis, samples were rapidly thawed in a $30^{\circ} \mathrm{C}$ water bath and fluorescent beads of $10 \mu \mathrm{m}$ in diameter 
were added in order to normalize the flow cytometer settings and to provide a reference for concentration calculations. The sample and sheath fluid rates were 1 and $100 \mathrm{~mm}^{3} \mathrm{~s}^{-1}$ respectively.

Data were collected and stored in list-mode on a personal computer with the IMMUNOCOUNT software (ORTHO Diagnostic Systems). Due to the control of the sample volume by a micro-syringe, this software can directly provide cell concentrations (cells mm $\mathrm{mm}^{-3}$ ). The Winlist software (Verity Software, USA) was used to determine statistical data. We must mention that the Prochlorococcus ecotype adapted to high light was likely underestimated in our measurements due to its low fluorescence level.

The cell concentration of each cluster was integrated at each station between 0 to $200 \mathrm{~m}$ depth with the trapezoid method. Interpolation of integrated cell concentration and cartography were realized with the ODV software (Schlitzer, 2002) over the domain occupied by sampled stations.

\subsection{Biomass estimation}

Synechococcus abundances were converted in carbon biomasses by using the estimation of $200 \mathrm{fgCcell}^{-1}$ (Mackey et al., 2002). The content of $49 \mathrm{fg} \mathrm{C} \mathrm{cell}^{-1}$ was applied to Prochlorococcus (Caillau et al., 1996). For pico- and nano-eukaryotes, averaged biovolumes ( 4.48 and $113.10 \mu \mathrm{m}^{3}$ respectively) were calculated by using equivalent diameters estimated from flow cytometry and used into the equation of Verity et al. (1992):

$C(\mathrm{pg})=\operatorname{coeff} \cdot \operatorname{biovolume}\left(\mu \mathrm{m}^{3}\right)^{0.866}$

with coeff values of 0.405 and 0.239 for pico- and nanoeukaryotes respectively. These values were derived from the curve constructed by using the set of coeff-cell size in Verity et al. (1992).

The resulting carbon biomasses per cell are 1.393 and $14.133 \mathrm{pg} \mathrm{C} c e l l^{-1}$ for pico- and nanoeukaryotes respectively.

\subsection{Pigment and nutrient analysis}

Pigments (chlorophylls and carotenoïds) were collected at the same stations and depths as samples for flow cytometric analysis. Pigments were analyzed by HPLC with the method of Vidussi et al. (1996) as detailed in Vidussi et al. (2001). Total chlorophyll $a$ (total $\mathrm{Chl} a$ ) was calculated as the sum of chlorophyll $a$ and divinyl-chlorophyll $a$. The total Chl $a$ concentrations determined by HPLC during this cruise were integrated over the $0-200 \mathrm{~m}$ layer and converted in terms of carbon by using the conversion factor $\mathrm{C} / \mathrm{Chl} a=50$ (Brown et al., 1999), assuming a constant ratio in the study area.

Nutrient samples were collected in acid-washed $50 \mathrm{~cm}^{3}$ polypropylene bottles. Nitrate $\left(\mathrm{NO}^{3-}\right)$, phosphate $\left(\mathrm{PO}_{4}^{3-}\right)$ and silicate $\left(\mathrm{Si}(\mathrm{OH})_{4}\right)$ were analyzed on board within a few hours after recovery of the rosette, or frozen until analysis, using a Technicon Auto-Analyser II according to the procedures described by Grasshoff (1983). Precision of the method, calculated from five replicates, was $\pm 0.04 \mu \mathrm{M}$ $(C v<5 \%)$ for $\mathrm{NO}^{3-}, \pm 0.02 \mu \mathrm{M}(\mathrm{Cv}<2 \%)$ for $\mathrm{Si}(\mathrm{OH})_{4}$ and $\pm 0.003 \mu \mathrm{M}$ for $\mathrm{PO}_{4}^{3-}(C v<4 \%)$.

\section{Results}

\subsection{Water mass properties and their horizontal and vertical distributions in the upper ocean}

\subsubsection{The water masses of the eastern Mediterranean Sea}

The water mass properties and their transformation throughout the eastern Mediterranean Sea were analyzed by potential temperature/salinity diagrams constructed separately for three regions: (i) the Ionian basin, (ii) the Cretan Passage, and (iii) the Levantine basin. See supplementary material for more details.

\subsubsection{Horizontal analyses}

The horizontal maps at surface were constructed for the temperature, salinity and density fields in order to illustrate the spatial distribution of the AW, LSW (Levantine surface waters) and their dynamics, as well. In spite of the large seasonal variability of the upper dynamics indicated by the model simulations (Roussenov et al., 1995), which have shown a prevalent eastward flow pattern of AW in winter, in January 1995 the salinity pattern revealed instead that both the western and northern Ionian basin were under the influence of the low-salinity AW (see supplementary material).

\subsubsection{Zonal section throughout the eastern Mediterranean Sea}

The spatial structure of the hydrographic fields in the upper layer is depicted in the vertical distributions of temperature, salinity, density and dissolved oxygen down to $200 \mathrm{~m}$ and along the transect throughout the eastern Mediterranean Sea (Fig. 2). In particular, the transect crosses the middle Ionian basin, the northern side of the Cretan Passage and the convection region in the northern Levantine basin. The vertical extent of the AW within the Ionian basin appeared by the low salinity values down to about $200 \mathrm{~m}$. Moreover, the AW exhibited dissolved oxygen values higher than those in the underlying water, which was characterized by high salinity and low oxygen contents, indicating the LIW (Fig. 2b).

The behaviour of isotherms, isohalines and isopycnals in the Ionian basin indicated the presence of a bowl corresponding to the broad Ionian Anticyclone (Malanotte-Rizzoli et al., 1999), which developed down to $800 \mathrm{~m}$ (see supplementary material) entraining AW at surface and LIW in its interior. 

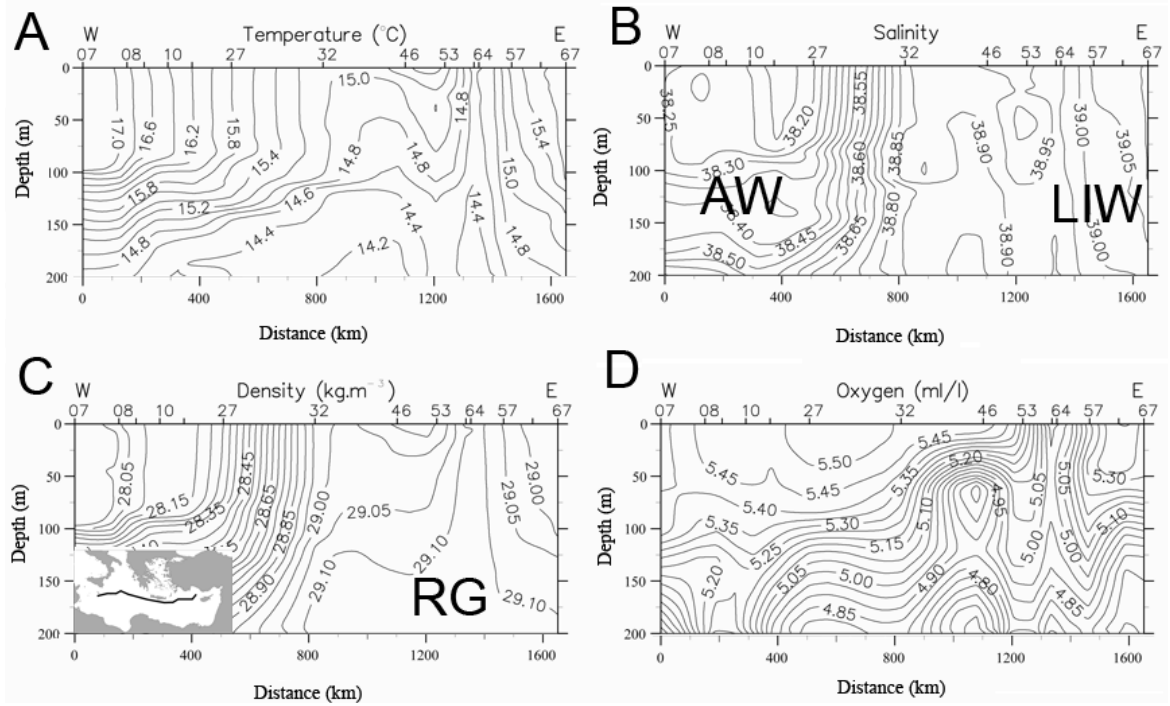

Fig. 2. Vertical distribution of (A) temperature, (B) salinity, (C) density, and (D) dissolved oxygen down to $200 \mathrm{~m}$ along the cross section through the eastern Mediterranean Sea (see inset map) in January 1995. The positions of the Atlantic waters (AW), the Levantine Intermediate Waters (LIW) and the Rhodes Gyre (RG) are also indicated. For the positions of the Ionian Anticyclone and the Cretan Cyclone, see supplementary material.

Thus, a frontal system was established at the surface between the relatively fresh AW on the left and the highly saline Levantine type waters on the right (Fig. 2b). In contrast, the isopycnals slope upwarded from the west to the east and the doming structures prevailed in the Cretan Passage and in the Levantine basin. Two very strong divergence zones might be noticed. The first one was located in the Cretan Passage between the stations 32 and 46 and the second one was located in the Levantine basin (station 64). The former corresponds to the Cretan cyclone and was marked by the outcropping of the isotherm $15^{\circ} \mathrm{C}$ and the isopycnal $29.0 \mathrm{~kg} \mathrm{~m}^{-3}$ (Fig. 2a and c). The latter, much more intense, marked the Rhodes gyre where the isotherm $14.5^{\circ} \mathrm{C}$ and the isopycnal $29.12 \mathrm{~kg} \mathrm{~m}^{-3}$ were ventilating, being in direct contact with the atmosphere at the station 64. The LIW convectively formed on the periphery of the Rhodes gyre (LIWEX Group, 2003) may be recognized from the higher values of salinity and dissolved oxygen (Fig. $2 b$ and d). Features of the 200$800 \mathrm{~m}$ depth layer are available in supplementary material.

Nutrient concentrations followed the hydrographic trends. $\mathrm{NO}^{3-}$ concentrations in the $\mathrm{AW}$ ranged from undetectable values in the upper layer to a maximum of $2.75 \mu \mathrm{M}$ at $200 \mathrm{~m}$ and increased in the LIW to reach $2.5 \mu \mathrm{M}$ in the surface waters and $\sim 4 \mu \mathrm{M}$ at $200 \mathrm{~m}$ (Fig. 3a). $\mathrm{PO}_{4}^{3-}$ concentrations in the AW were $<0.0025 \mu \mathrm{M}$ in the upper layer to $<0.05$ at 200 $\mathrm{m}$, while in the LIW, values ranged from $0.0025-0.05 \mu \mathrm{M}$ to $0.075-1 \mu \mathrm{M}$ from surface to $200 \mathrm{~m}$ (Fig. 3b). $\mathrm{Si}(\mathrm{OH})_{4}$ concentrations in the AW were homogenized with values between 1 and $2 \mu \mathrm{M}$ from surface to $200 \mathrm{~m}$ while in the LIW, surface values ranged from 2 to $4 \mu \mathrm{M}$ and from 4 to $5 \mu \mathrm{M}$ at $200 \mathrm{~m}$ (Fig. 3c).

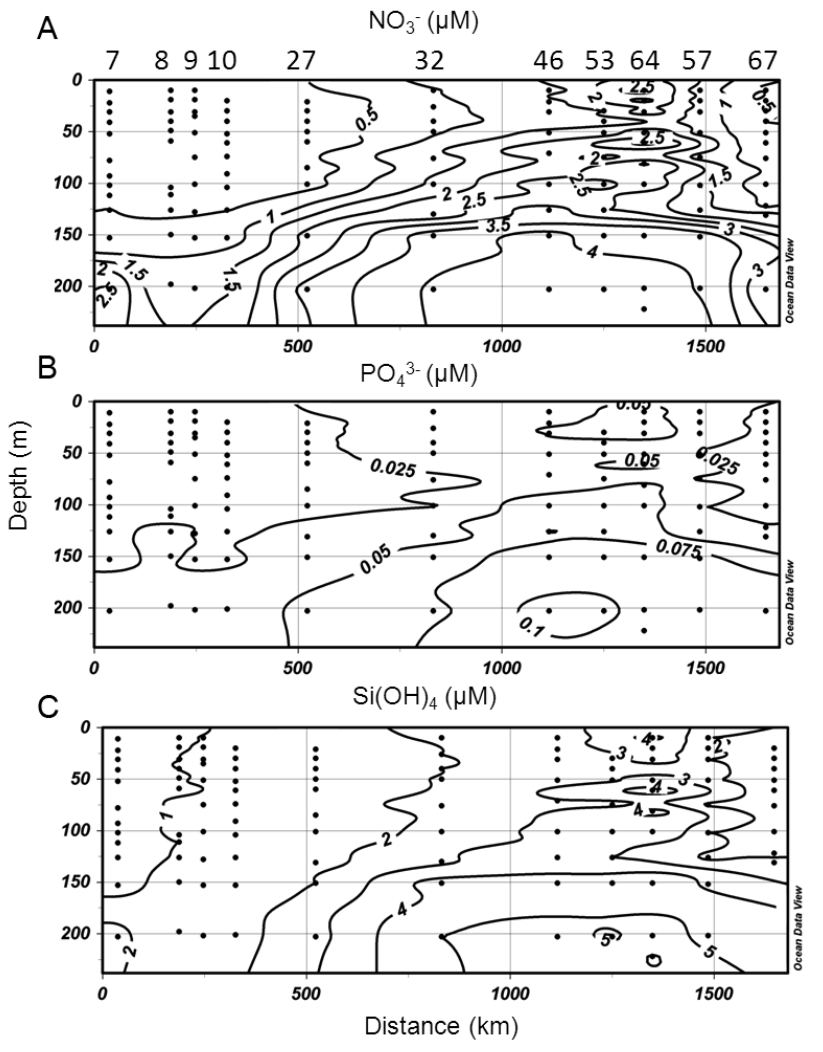

Fig. 3. Vertical distribution of (A) nitrate $\left(\mathrm{NO}_{3}^{-}\right)$, (B) phosphate $\left(\mathrm{PO}_{4}^{3-}\right)$ and $(\mathrm{C})$ silicate $\left(\mathrm{Si}(\mathrm{OH})_{4}\right)$ down to $200 \mathrm{~m}$ along the cross section through the eastern Mediterranean Sea (similar to Fig. 2). Stations are indicated on the top of the $\mathrm{x}$ axis. 
Table 1. MLD calculated from a threshold method at which changes in density from that at the reference depth of $2 \mathrm{~m}$ are greater than the threshold value $(\Delta \sigma \theta)$ as indicated.

\begin{tabular}{rrrrrrrrr}
\hline \multicolumn{3}{c}{ Western Ionian basin } & \multicolumn{3}{c}{ Eastern Ionian basin } & \multicolumn{3}{c}{ South Adriatic basin } \\
Station & $\begin{array}{r}\Delta \sigma \theta \\
\mathrm{kg} \mathrm{m}^{-3}\end{array}$ & $\begin{array}{r}\text { MLD } \\
\mathrm{m}\end{array}$ & Station & $\begin{array}{r}\Delta \sigma \theta \\
\mathrm{kg} \mathrm{m}^{-3}\end{array}$ & $\begin{array}{r}\text { MLD } \\
\mathrm{m}\end{array}$ & Station & $\begin{array}{r}\Delta \sigma \theta \\
\mathrm{kg} \mathrm{m}^{-3}\end{array}$ & $\begin{array}{r}\mathrm{MLD} \\
\mathrm{m}\end{array}$ \\
\hline 5 & 0.02 & 98 & 24 & 0.02 & 68 & 15 & 0.05 & 83 \\
6 & 0.02 & 66 & 25 & 0.02 & 60 & 16 & 0.05 & 39 \\
7 & 0.02 & 94 & 26 & 0.05 & 34 & 17 & 0.02 & 463 \\
8 & 0.02 & 58 & 27 & 0.05 & 71 & 18 & 0.02 & 92 \\
& & & 28 & 0.02 & 103 & 19 & 0.02 & 101 \\
& & & 29 & 0.02 & 111 & & & \\
\hline
\end{tabular}

\subsubsection{Mixed layer depth}

MLD was computed for selected stations as shown in Table 1 . Through the Sicily Straits the MLD maxima with values around $100 \mathrm{~m}$ were found in the western and eastern straits, while in the middle it was closer to $70 \mathrm{~m}$. In the eastern Ionian basin the MLD was $>100 \mathrm{~m}$ in those regions dominated by the anticyclonic motion (station 28-29) that entrained in its interior Atlantic Water. The front region was easily identified by the existing horizontal gradients in temperature and salinity towards the north-east that yielded a much shallower MLD ( $\sim 65 \mathrm{~m})$. The mixed layer exhibited the strongest vertical uniformity in the south Adriatic basin reaching a depth of $463 \mathrm{~m}$ at station 17, where within an isolated chimney the convective overturning involved low temperature $\left(\sim 13^{\circ} \mathrm{C}\right)$ and highly saline water masses $(S \sim 38.7)$.

\subsection{Ultraphytoplankton distribution}

Ultraphytoplanktonic cells $(<10 \mu \mathrm{m})$ analyzed by flow cytometry were resolved in four clusters on the basis of their optical properties, namely nanoeukaryotes $(3-10 \mu \mathrm{m})$, picoeukaryotes $(<3 \mu \mathrm{m})$, Prochlorococcus and Synechococcus. The vertical distribution in the upper $200 \mathrm{~m}$ of each group varied independently according to depth and location. The geographic distribution of 0-200 $\mathrm{m}$ integrated abundances of nanoeukaryotes, picoeukaryotes, Prochlorococcus, and Synechococcus in the eastern Mediterranean Sea and in four stations in the western Mediterranean Sea can be seen in supplementary material. Minimal and maximal values of the four cluster integrated abundances and biomasses are reported in Table 2. Nanoeukaryotes were poorly represented in the Ionian basin (stations 7 to 30 ) ( 1.4 to $3.7 \times 10^{10}$ cells $\mathrm{m}^{-2}$ ) and in the centre of the gyre in the south Adriatic basin $\left(3.4 \times 10^{10}\right.$ cells m $\left.{ }^{-2}\right)$, whereas their integrated abundances were about twice as high (up to $6.6 \times 10^{10}$ cells $\mathrm{m}^{-2}$ ) in the Sicily Strait (station 5), in the Strait of Otranto (station 15) and in the southern Adriatic basin (stations 16-19). In the Levantine basin, the nanoeukaryote integrated abundances were higher than in
Table 2. Range of variation of the integrated abundances and biomasses of the different ultraphytoplankton groups in the eastern Mediterranean Sea. Maximum and minimum values are associated with the stations where they have been observed. Biomasses were determined as detailed in Materials and Methods.

\begin{tabular}{llrrr}
\hline \multirow{2}{*}{ Nanoeukaryotes } & Max & $\begin{array}{r}\text { Integrated } \\
\text { abundance } \\
10^{10} \text { cells m }^{-2}\end{array}$ & $\begin{array}{r}\text { Integrated } \\
\text { biomass } \\
\mathrm{mg} \mathrm{C} \mathrm{m}^{-2}\end{array}$ & Station \\
& Min & 12.5 & 1763.1 & 57 \\
Picoeukaryotes & Max & 1.4 & 202.4 & 9 \\
& Min & 34.9 & 453.3 & 34 \\
Prochlorococcus & Max & 1.4 & 18.2 & 49 \\
& Min & 117.6 & 57.6 & 24 \\
& Max & 285.6 & 57.1 & 44 \\
& Min & 33.9 & 67.7 & 47 \\
\hline
\end{tabular}

the Ionian basin $\left(>6 \times 10^{10}\right.$ cells $\left.^{-2}\right)$, particularly between Cyprus and Crete islands $\left(8.3\right.$ to $12.5 \times 10^{10}$ cells m$^{-2}$ ) and in the Rhodes gyre (station $57,12.5 \times 10^{10}$ cells m$^{-2}$ ).

At most stations, integrated concentration values for picoeukaryotes were higher than those for nanoeukaryotes (between 5 to $35 \times 10^{10}$ cells m$^{-2}$ ), but their distribution over the eastern Mediterranean Sea followed the same pattern (see supplementary material).

Integrated Prochlorococcus abundances in the eastern Mediterranean Sea were low and homogeneous at the level of the Ionian basin, in the centre of the southern Adriatic gyre and in the western side of the Levantine basin. In contrast, the integrated concentrations of Prochlorococcus were higher near the Greek coast at stations 24 and $25\left(117.6 \times 10^{10}\right.$ cells m$\left.^{-2}\right)$, in the Otranto Strait and in the southern Adriatic basin, at the periphery of the gyre, i.e. along the pattern followed by the Ionian Surface water that intruded into the Adriatic basin through the Strait of Otranto. 
In the Levantine basin, integrated abundances were relatively high (stations 55 to 74 , up to $60.8 \times 10^{10}$ cells m$^{-2}$ ) except in the Rhodes gyre where they were about two fold lower $\left(\sim 30 \times 10^{10}\right.$ cells m$^{-2}$, station 61$)$. Prochlorococcus integrated abundances at stations sampled in the western Mediterranean Sea were at the same levels as in the Ionian basin ( 14.1 to $24.7 \times 10^{10}$ cells $\mathrm{m}^{-2}$ ).

Synechococcus was the most abundant (in terms of cell numbers) population, constituting from $17 \%$ (station 5) to $68 \%$ (station 30) of the overall ultraphytoplankton community integrated abundances. In the southern Adriatic basin, at the periphery of the gyre (stations 19 and 16) and at the Otranto Strait (station 15), the water masses were from 4 to 5 times richer in Synechococcus than those at the centre of the gyre (station 17). Synechococcus integrated abundances were low in the western Ionian basin $\left(<120 \times 10^{10}\right.$ cells m$^{-2}$; stations 5 to 9$)$ and increasing progressively towards the centre of the eastern Mediterranean Sea. However, these values were not homogeneously distributed: for example, integrated abundances varied by an order of magnitude from $37.4 \times 10^{10}$ cells m$^{-2}$ (station 41 ; Aegean basin) to $285.6 \times 10^{10}$ cells m$^{-2}$ (station 47 ; eastern Cretan Passage). High abundances in Synechococcus were observed in the area occupied by the Ierapetra anticyclone located south of Crete (stations 47, 51, 54; mean concentration: $275 \times 10^{10}$ cells $^{-2}$ ); indeed, the highest value (Table 2) was found within this gyre. In the Rhodes gyre (stations 51-71), the Synechococcus integrated abundances were relatively low except at station $71\left(226.0 \times 10^{10}\right.$ cells m$\left.^{-2}\right)$. In the western Mediterranean Sea, the 4 sampled stations (2-5) were relatively poor in Synechococcus, with integrated abundances in the range 26.2 to $45.4 \times 10^{10}$ cells m$^{-2}$. It is worthy to remark that these values are close to the three lowest values $\left(33.8,37.4\right.$ and $41.9 \times 10^{10}$ cells m$\left.^{-2}\right)$ observed in the eastern Mediterranean Sea, but in the convective regions; i.e. at stations 17, 41 and 58 located in the southern Adriatic basin, in the Aegean basin and in the Rhodes gyre, respectively. Synechococcus was largely dominant over Prochlorococcus, thus the cyanobacteria specific pigment zeaxanthin quantified by HPLC was exclusively assigned to Synechococcus during this study and the cell content in zeaxanthin was found depth-independent (not shown).

The carbon biomass derived from integrated $\mathrm{Chl} a$ concentrations analyzed by HPLC using a constant $\mathrm{C} / \mathrm{Chl} a$ ratio of 50 varied between 541 to $2549 \mathrm{mg} \mathrm{C} \mathrm{m}^{-2}$, with a mean value of $1122 \mathrm{mg} \mathrm{C} \mathrm{m}^{-2}$. The contribution percentage of Synechococcus and Prochlorococcus to this biomass was estimated for all stations using cell concentrations and a carbon per cell ratio as detailed in the materials and methods section (Table 3). Synechococcus contributed 3.3 to $67.7 \%$ to the total phytoplankton biomass, with the lowest contribution at station 17 (cyclonic gyre) and the highest south of Cyprus (station 74, Shikmona anticyclone). The Synechococcus contribution was also very high in the Ierapetra anticyclone (45.7\%, station 47). Prochlorococcus con- tributed weakly to the total phytoplanktonic biomass (from $0.5 \%$ at the Sicily Strait to $6.5 \%$ at station 24 influenced by the cyclonic eddy).

\subsection{Links between ultraphytoplankton distributions, meso-scale dynamics and nutrients}

Ultraphytoplankton and nutrient vertical distributions were investigated in some details in those regions that were dynamically active, exhibiting relatively higher phytoplankton abundances even though locally limited.

\subsubsection{Southern Adriatic basin}

Figure 4a shows the vertical distribution of temperature, salinity and density in the southern Adriatic basin. Typical aspects of winter convection are shown at station 17 located in the centre of the cyclonic gyre, where uniform hydrographic properties $\left(t \approx 13.25^{\circ} \mathrm{C}, S \approx 38.65\right.$, and density $\approx 29.18 \mathrm{~kg} \mathrm{~m}^{-3}$ ) in the $0-200 \mathrm{~m}$ clearly attest the extent of the convective mixing of the water column; in contrast, $40 \mathrm{~km}$ far from the centre of the gyre (station 16 and 19), a thermohaline stratification persists because of the strong gradient between the relatively fresh water from the northern regions and the LIW entrained in the cyclonic circulation pattern (see supplementary material). It is worthy to notice the thermal inversion with depth through the 50 and $150 \mathrm{~m} \mathrm{lev-}$ els; the vertical stability of the water column is maintained by the salinity. Thus, three water masses can be distinguished in the upper $200 \mathrm{~m}$ layer: (i) the relatively fresh waters of riverine input in the upper $50 \mathrm{~m}$; (ii) the coldest and dense water from the northern shelf regions $(50-100 \mathrm{~m}$ ); and (iii) the transitional layer towards the warmer, saline intrusion of the much more dense LIW in the beneath. The eddy field showed that maximum salinity cores of LIW were trapped in the gyre, resulting in a vertical distribution of more saline waters at station 17, whilst the fresher and lighter waters of riverine input, mainly flowing from the northern Adriatic region, were entrained around the gyre (station 16 and 19); these waters were transported to the south by the western Adriatic Costal Current (Artegiani et al., 1997), and might be traced as far as the Strait of Otranto (station 15).

In the southern Adriatic basin, the three ultraphytoplanktonic populations showed a uniform vertical distribution at the centre of the gyre (Fig. 4b) with low integrated abundances of about $3.4,23.3$ and $33.8 \times 10^{10}$ cells m$^{-2}$ for nanoeukaryotes, Prochlorococcus and Synechococcus, respectively (station 17). On the other hand, variable quantities towards higher integrated abundances were outside, at the periphery of the gyre (stations 16 and 19), and at the Otranto Strait (station 15). Nutrient distribution pattern was very similar (Fig. 4c). Station 17 exhibited homogeneous values from surface to $200 \mathrm{~m}$ for $\mathrm{NO}^{3-}(\sim 5 \mu \mathrm{M}), \mathrm{PO}_{4}^{3-}(\sim 0.12 \mu \mathrm{M})$ and $\mathrm{Si}(\mathrm{OH})_{4}(\sim 7 \mu \mathrm{M})$. Nutrient concentrations at station 15 and 16 were similar, $\mathrm{NO}^{3-}$ concentrations ranged between 1 and 
Table 3. Percentage of contribution of Synechococcus and Prochlorococcus to the overall chlorophyll $a$ biomass. To calculate these contributions, chl $a$ was expressed in terms of carbon biomass by using the ratio $\mathrm{C} / \mathrm{Chl} a=50$.

\begin{tabular}{lccccc}
\hline Station & \multicolumn{2}{c}{ \% of contribution to chl $a$ biomass } & Station & \multicolumn{2}{c}{ \% of contribution to chl $a$ biomass } \\
& Synechococcus & Prochlorococcus & & Synechococcus & Prochlorococcus \\
\hline 2 & 9.5 & 1.5 & 32 & 20.0 & 1.2 \\
3 & 4.6 & 0.9 & 33 & 15.0 & 1.2 \\
4 & 6.1 & 1.4 & 34 & 14.7 & 1.1 \\
5 & 5.9 & 0.5 & 36 & 23.1 & 1.1 \\
7 & 14.5 & 1.3 & 38 & 31.4 & 2.2 \\
8 & 29.6 & 2.1 & 40 & 17.3 & 1.9 \\
9 & 25.5 & 1.6 & 41 & 6.9 & 1.3 \\
10 & 34.8 & 2.5 & 43 & 14.4 & 1.7 \\
11 & 32.7 & 1.9 & 44 & 11.7 & 0.8 \\
14 & 20.6 & 2.4 & 47 & 45.7 & 1.3 \\
15 & 20.9 & 3.0 & 49 & 35.6 & 2.2 \\
16 & 22.3 & 1.7 & 50 & 24.5 & 1.5 \\
17 & 3.3 & 0.6 & 51 & 36.7 & 2.7 \\
19 & 17.1 & 0.9 & 54 & 21.2 & 1.3 \\
20 & 14.7 & 1.6 & 55 & 10.9 & 1.3 \\
21 & 22.1 & 1.9 & 57 & 17.3 & 1.2 \\
23 & 27.6 & 1.7 & 58 & 6.6 & 1.5 \\
24 & 28.3 & 6.5 & 61 & 15.1 & 2.5 \\
25 & 22.9 & 4.5 & 62 & 22.8 & 1.3 \\
27 & 30.4 & 1.8 & 69 & 18.6 & 3.5 \\
28 & 38.4 & 2.0 & 71 & 24.3 & \\
29 & 36.0 & 3.2 & 73 & 25.2 & 67.7 \\
30 & 33.3 & 1.6 & 74 & & \\
31 & 31.3 & 1.6 & & & \\
\hline
\end{tabular}

$2 \mu \mathrm{M}$ at surface and reached station 17's values of $\sim 5 \mu \mathrm{M}$ at $200 \mathrm{~m}, \mathrm{PO}_{4}^{3-}$ concentration values were of $\sim 0.02 \mu \mathrm{M}$ at surface and $\sim 0.12 \mu \mathrm{M}$ at $200 \mathrm{~m}$ and $\mathrm{Si}(\mathrm{OH})_{4}$ values were of $\sim 2.5 \mu \mathrm{M}$ at surface and reached between 6 and $8 \mu \mathrm{M}$ at $200 \mathrm{~m}$ (Fig. 4c).

Generally, the two sites are dynamically related by cyclonic circulation that causes the exchange of Adriatic/Ionian waters across the Strait (i.e. Adriatic Surface Waters to the west and Ionian Surface waters to the east that outflow/intrude into the Ionian/Adriatic basin) probably more intensely during the winter (Gacic et al., 1996).

In order to show the impact of the hydrodynamic structure, i.e. the cyclonic gyre in the southern Adriatic basin, on the abundance of ultraphytoplankton and the concentration of nutrients, we looked for a possible relationship between density and cell abundance or nutrient concentration where hydrodynamism was strong enough. Two stations can be considered affected by a hydrodynamic feature when density values at a same depth and over a given depth range are different so that the slopes of the pycnoclines are very steep. With depth, the ratio of the density values at the compared stations tends toward one, which characterizes homogeneous deep layers. Considering station 17 in the core of the gyre and station 15 outside the gyre with a pycnocline at about $100 \mathrm{~m}$ depth, we found a significant linear relationship in the 50-150 m column between depth and the natural logarithm of Synechococcus abundance ratio $\operatorname{Syn}_{17} / \operatorname{Syn}_{15}$ as shown in Fig. 5a. We also found a significant linear relationship between the density ratio $\sigma_{17} / \sigma_{15}$ and depth in the $50-150 \mathrm{~m}$ layer as illustrated by Fig. $5 \mathrm{~b}$. A significant linear $\left(r^{2}=0.91, p<0.01\right)$ regression was found between abundance and density ratios: $\operatorname{Syn}_{17} / \operatorname{Syn}_{15}=a\left(\sigma_{17} / \sigma_{15}\right)+b$ (Fig. 5c). A significant linear regression was also found between nutrient (nitrate, phosphate) and density ratios (see Table 4). Relationships between pico- and nanoeukaryotes and depth or density were not significant (Table 4). At station 16, the pycnocline was shallower $(30-40 \mathrm{~m})$ and the significant relationship involving Synechococcus abundances at stations 17 and 16 took the form of a power function (Table 4). It was also the case for the relationship involving nutrient and density ratios at stations 16 and 17 . In that case, the similar relationships for pico- and nanoeukaryotes were significant (Table 4).

\subsubsection{Eastern Ionian basin}

The vertical distribution of the hydrographic measurements in the eastern Ionian basin was analyzed along the 
Table 4. Correlation coefficients $\left(R^{2}\right)$ of linear relationships between ratios at a given depth $\left(z_{i}\right)$ below $50 \mathrm{~m}$ of cell abundance or nutrient concentrations $A\left(z_{i}\right)$ and density excess $\sigma\left(z_{i}\right)$ or salinity $S\left(z_{i}\right)$ at two compared stations. Linear relationships were also established between depth and the ratio of density excess or salinity at the two compared stations. The compared stations and the range of depth where the linear relationships were established are given in the first column. The linear relationships are explicitely written for stations 25 and 27 and for station 7 and 5 as two examples.

\begin{tabular}{|c|c|c|c|c|c|c|}
\hline & & \multicolumn{3}{|c|}{$A_{25}\left(z_{i}\right) / A_{27}\left(z_{i}\right)=a * \sigma_{25}\left(z_{i}\right) / \sigma_{27}\left(z_{i}\right)+b$} & $z=a * \sigma_{25}(z) / \sigma_{27}(z)+b$ & $z=a * S_{25}(z) / S_{27}(z)+b$ \\
\hline & $\mathrm{n}$ & Synechoccocus & Picoeukaryote & Nanoeukaryote & & \\
\hline st 25-27 (85-200 m) & 6 & $0.89^{*}$ & 0.68 & 0.08 & $0.96^{* *}$ & \\
\hline st $16-17(50-200 \mathrm{~m})$ & 6 & $0.80^{*}$ & $0.83^{*}$ & $0.79^{*}$ & $0.92^{* *}$ & \\
\hline \multirow[t]{2}{*}{ st $15-17(50-200 \mathrm{~m})$} & 6 & $0.92^{* *}$ & 0.52 & 0.47 & $0.92^{* *}$ & \\
\hline & & $\mathrm{NO}_{3}^{-}(\mu \mathrm{M})$ & $\mathrm{PO}_{4}^{3-}(\mu \mathrm{M})$ & $\mathrm{Si}(\mathrm{OH})_{4}(\mu \mathrm{M})$ & & \\
\hline st $25-27(85-200 \mathrm{~m})$ & - & $0.99^{* *}(n=4)$ & $0.73 *(n=5)$ & $0.96^{* *}(\mathrm{n}=5)$ & & \\
\hline st $16-17(50-200 \mathrm{~m})$ & 7 & $0.99^{* *}$ & $0.91^{* *}$ & $0.86^{* *}$ & & \\
\hline \multirow[t]{3}{*}{ st $15-17(50-200 \mathrm{~m})$} & - & $0.93^{* *}(n=4)$ & $0.99^{* *}(n=6)$ & $0.96^{* *}(n=4)$ & & \\
\hline & \multicolumn{5}{|c|}{$A_{7}\left(z_{i}\right) / A_{5}\left(z_{i}\right)=a * S_{7}\left(z_{i}\right) / S_{5}\left(z_{i}\right)+b$} & \\
\hline & $\mathrm{n}$ & Synechoccocus & Picoeukaryote & Nanoeukaryote & & \\
\hline \multirow[t]{2}{*}{ st $7-5(50-200 \mathrm{~m})$} & 6 & 0.31 & $0.87^{*}$ & $0.75^{*}$ & 0.45 & $0.81^{*}$ \\
\hline & & $\mathrm{NO}_{3}^{-}(\mu \mathrm{M})$ & $\mathrm{PO}_{4}^{3-}(\mu \mathrm{M})$ & $\mathrm{Si}(\mathrm{OH})_{4}(\mu \mathrm{M})$ & & \\
\hline st $7-5(50-200 \mathrm{~m})$ & 6 & $0.87^{*}$ & $0.84^{*}$ & 0.53 & & \\
\hline
\end{tabular}

$* p<0.05 * * p<0.01$.

north-south transect defined by stations 24 to 29 , which crosses the area where we observed eddy fields (see supplementary material). The vertical sections provide evidence of the formation of a thermohaline front located between stations 25 and 27 (Fig. 6). The front extended down to $200 \mathrm{~m}$, separating two different water masses: (i) the cold and more saline to the north stations (24 and 25), and (ii) the warmer and less saline to the south of the front (stations 27-29). It appears evident from these distributions that the space scales of the eddy were about $100 \mathrm{~km}$; water mass analysis for this eddy fields showed that the LIW (i.e. a cold, more saline, poor in oxygen water mass with density of $\approx 28.85 \mathrm{~kg} \mathrm{~m}^{-3}$ ) entrained in the cyclonic circulation and upwelled close to the photic layer, but no convective mixing occurred because of the strong pycnocline established by the density structure. On the other hand, minimum salinity cores of AW were trapped in the anticyclone found in the southern region. The chemical features of these water masses were also different. In particular, concentration of dissolved oxygen was lower in the north than in the south (Fig. 6d), while $\mathrm{NO}^{3-}, \mathrm{PO}_{4}^{3-}$ and $\mathrm{Si}(\mathrm{OH})_{4}$ concentrations were higher, specifically between 60 and $200 \mathrm{~m}$ (Fig. 7a, b and c respectively).

The impact of this thermohaline front on the vertical distribution of ultraphytoplankton is illustrated by Fig. 8. For pico- and nanoeukaryotes, the transition across the front resulted essentially in their deeper presence south of the front than at station 25 , especially down to $100 \mathrm{~m}$. In contrast, the vertical distributions of Synechococcus and Prochlorococcus were more affected by the front. Indeed, north of the front, the two distributions were complementary, Synechococcus occupying the upper $75 \mathrm{~m}$ and Prochlorococcus being present below, between 75 and $150 \mathrm{~m}$, with about the same maximum concentration $\left(\approx 20000\right.$ cells $\left.\mathrm{cm}^{-3}\right)$ whereas south of the front Synechococcus was present deeper (down to $150 \mathrm{~m}$ ) and Prochlorococcus concentration decreased and dropped below 1000 cells $\mathrm{cm}^{-3}$ throughout the water column.

At station 25, we observed a strong vertical variation of density between 60 and $75 \mathrm{~m}$ depth (Fig. 6c) that was coupled to a large abundance decline for all ultraphytoplankton groups before $100 \mathrm{~m}$ depth. At station 27 where the vertical variation of density was smoother (Fig. 6c), the ultraphytoplankton concentration declined more progressively with depth. We found a linear relationship between the ratio $\sigma_{25} / \sigma_{27}$ of density values and depth between 75 and $200 \mathrm{~m}$ at stations 25 and 27 (Fig. 9b). We also found a significant linear relationship in the same depth range $(75-200 \mathrm{~m})$ between depth and the natural logarithm of Synechococcus abundance ratio $\operatorname{Syn}_{25} / \mathrm{Syn}_{27}$ as shown in Fig. 9a. A significant $\left(r^{2}=0.89, p<0.05\right)$ correlation between abundance and density ratios: $\operatorname{Syn}_{25} / \operatorname{Syn}_{27}=a\left(\sigma_{25} / \sigma_{27}\right)+b$ was also found as shown in Fig. 9c. Similar relationships between depth and density or abundance ratios and between abundance ratios and density for pico- and nanoeukaryotes were not significant (Table 4). We also found a linear relationship between nutrient and density ratios in the range $85-200 \mathrm{~m}$ depth (Table 4). 


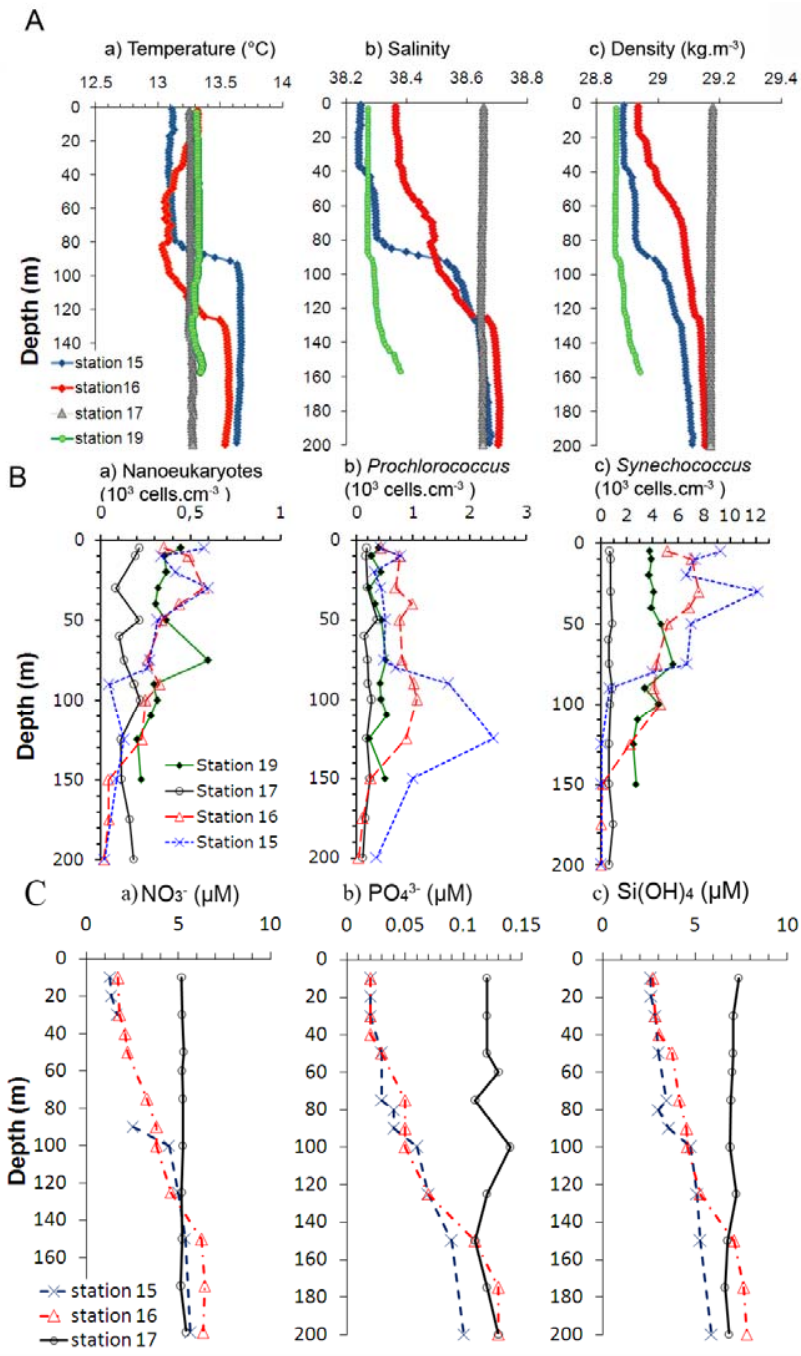

Fig. 4. Southern Adriatic basin features. A: profiles of (a) temperature, (b) salinity, and (c) density excess for the stations located in the southern Adriatic basin and in the Strait of Otranto. B: vertical distribution of (a) Nanoeukaryotes, (b) Prochlorococcus and (c) Synechococcus in the southern Adriatic basin and in the Strait of Otranto. (Note that different scales of abundance are used for the sake of the presentation). $\mathrm{C}$ : vertical distribution of (a) nitrate $\left(\mathrm{NO}^{3-}\right)$, (b) phosphate $\left(\mathrm{PO}_{4}^{3-}\right)$ and (c) silicate $\left(\mathrm{Si}(\mathrm{OH})_{4}\right)$ in the southern Adriatic basin and in the Strait of Otranto. Station 19 was not available.

\subsubsection{Transition from the eastern to the western Mediterranean Sea}

Differences between the eastern and western Mediterranean Sea were provided by stations sampled on both sides of the Sicily Strait, along the transect made by stations 2 to 10 . Indeed, the physical features of the water masses varied between stations 5 and 7 when crossing the Sicily Strait that makes the geographical separation between the western and eastern Mediterranean Sea. Temperature and salinity in the

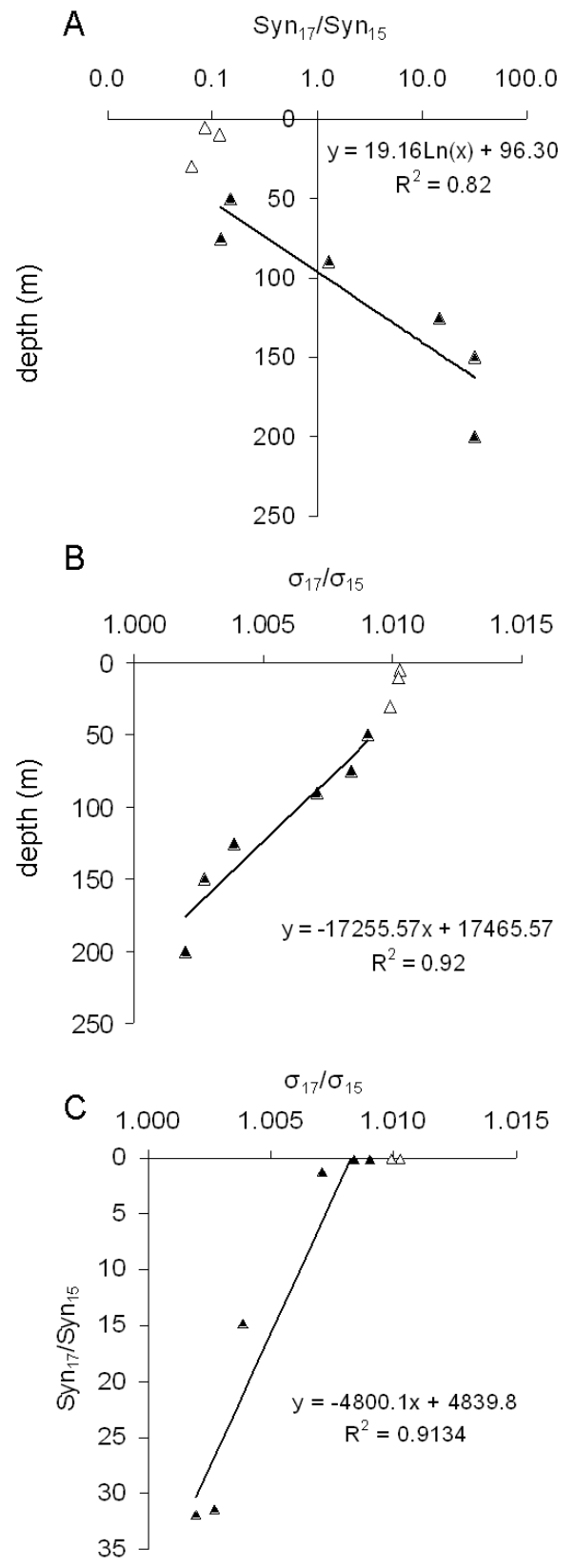

Fig. 5. Relationships between vertical distributions of Synechococcus abundance and density inside (station 17) and outside (station15) the south Adriatic gyre. (A) Depth dependence of the abundance ratio $\operatorname{Syn}_{17} / \mathrm{Syn}_{15}$. (B) Depth dependence of the density ratio $\sigma_{17} / \sigma_{15}$. (C) Relationship between Synechococcus abundance ratio $\operatorname{Syn}_{17} / \mathrm{Syn}_{15}$ and density ratio $\sigma_{17} / \sigma_{15}$. Data belonging to the upper $50 \mathrm{~m}$ (empty triangles) were excluded from the relationships (filled triangles).

surface layer were homogeneous west of the Sicily Strait and increased significantly in the eastern side of the transect, from 15.5 to $17.0^{\circ} \mathrm{C}$ and from 37.50 to 38.25 respectively (Fig. 10). In the upper $200 \mathrm{~m}$, nitrate, phosphate and silicate 

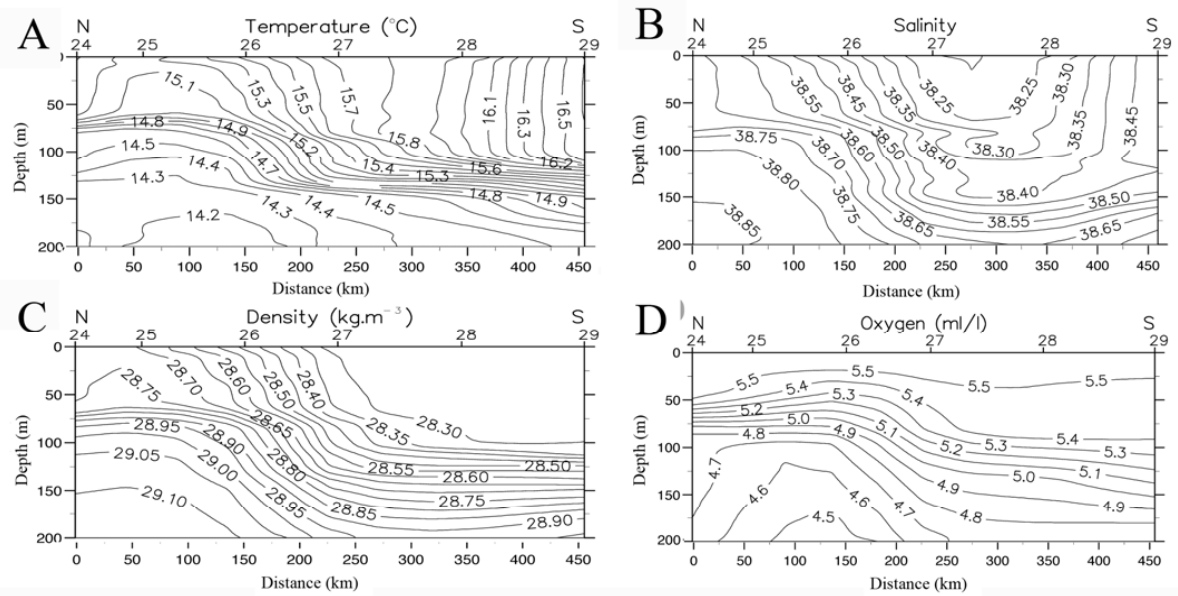

Fig. 6. Vertical distribution of (A) temperature, (B) salinity, (C) density and (D) dissolved oxygen along the north-south transect defined by stations 24 to 29. To note, the presence of an eddy field establishing a thermohaline front located between stations 25 and 27.

concentrations largely decreased eastwards. For instance, surface concentrations of nitrate decreased from about $6 \mu \mathrm{M}$ at station 2 to undetectable levels from station 4 to 10 and, at $200 \mathrm{~m}$, from $>9 \mu \mathrm{m}$ at station 2 to $<1.4 \mu \mathrm{M}$ at stations 8,9 and 10 (Fig. 11a). Similar trends were observed with $\mathrm{PO}_{4}^{3-}$ and $\mathrm{Si}(\mathrm{OH})_{4}$. Surface values of $\mathrm{PO}_{4}^{3-}$ at station 2 reached $0.12 \mu \mathrm{M}$ to values $<0.025 \mu \mathrm{M}$ from station 3 to 10 , and at $200 \mathrm{~m}$, values ranged eastward from $0.2 \mu \mathrm{M}$ to $<0.05 \mu \mathrm{M}$ (Fig. 11b). Eastward surface $\mathrm{Si}(\mathrm{OH})_{4}$ values ranged from 1$2 \mu \mathrm{M}$ to $<1 \mu \mathrm{M}$, and between 150 and $200 \mathrm{~m}$, from $4-6 \mu \mathrm{M}$ to $<2 \mu \mathrm{M}$ (Fig. 11c).

This abundance declined continuously further east. Prochlorococcus presented a contrasted distribution on both sides of the Sicily Strait, mainly occupying the upper $70 \mathrm{~m}$ on the west side, with abundances $>2000$ cells $\mathrm{cm}^{-3}$, whereas on the east side, abundances in the upper $70 \mathrm{~m}$ were $<1000$ cells $\mathrm{cm}^{-3}$, but were maximum at $100 \mathrm{~m}$ with values close to 4000 cells cm$~_{-3}$ (Fig. 12c). Synechococcus abundance was high at surface and decreased with depth (Fig. 12d). The peculiarity is that its abundance was higher in the eastern Basin $\left(10000\right.$ cells cm$~^{-3}$ at station 11) than in the western Basin ( 6000 cells cm $\mathrm{cm}^{-3}$ stations 2 to 5). In addition, the occupied layer was more important on the east side of the Sicily Strait $(0-80 \mathrm{~m})$ than on the west side $(<40 \mathrm{~m})$.

Nanoeukaryotes were mainly present in the upper $80 \mathrm{~m}$, with abundances slightly decreasing eastwards from about 400 to 300 cells cm$^{-3}$ (Fig. 12a). Picoeukaryotes were more abundant in the western Mediterranean Sea with a maximum value of 3000 cells cm$~^{-3}$ at $40 \mathrm{~m}$ depth, station 2 (Fig. 12b). At station 7, in the eastern Mediterranean Sea, picoeukaryote abundance was weaker $\left(\approx 1000\right.$ cells $\left.\mathrm{cm}^{-3}\right)$ and homogeneously distributed over the upper $100 \mathrm{~m}$.

The comparison of the eastern and western Mediterranean Sea does not directly involve hydrodynamic structures but rather water masses with different properties. The sur-

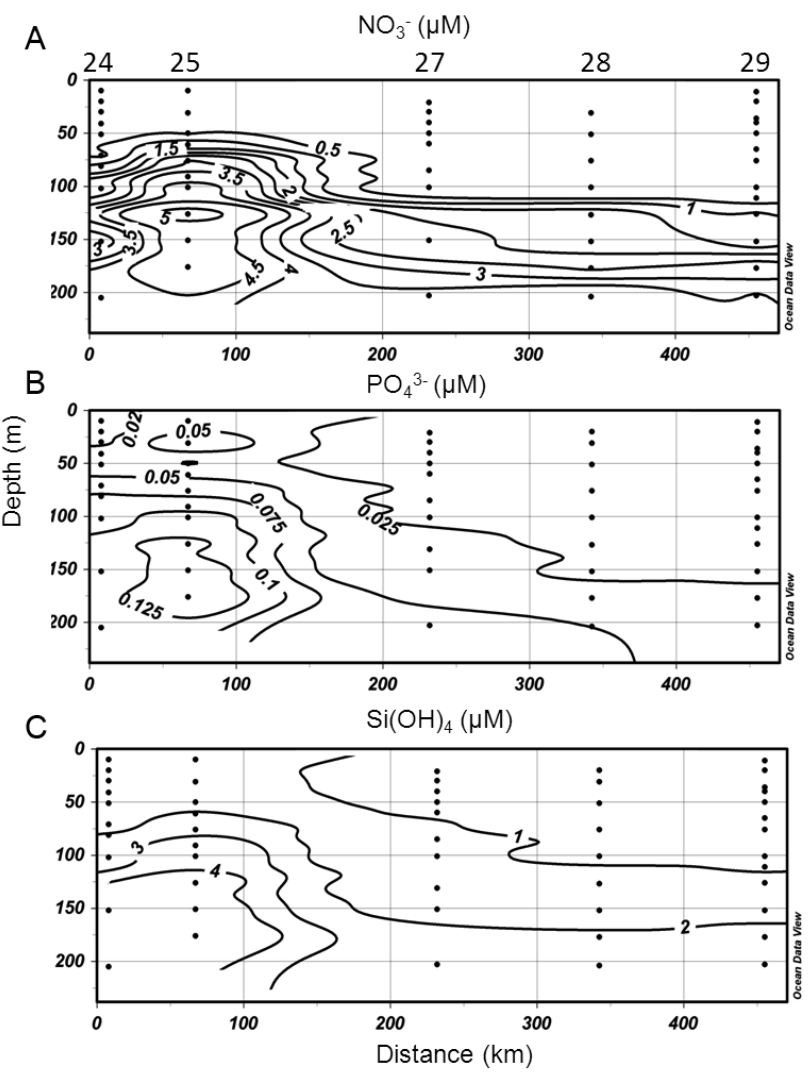

Fig. 7. Vertical distribution of (a) nitrate $\left(\mathrm{NO}^{3-}\right)$, (b) phosphate $\left(\mathrm{PO}_{4}^{3-}\right)$ and (c) silicate $\left(\mathrm{Si}(\mathrm{OH})_{4}\right)$ down to $200 \mathrm{~m}$ along the northsouth transect defined by stations 24 to 29 .

face of the western Mediterranean Sea under the influence of the Atlantic water inflow is less saline than the eastern Mediterranean Sea where evaporation is a major feature. 


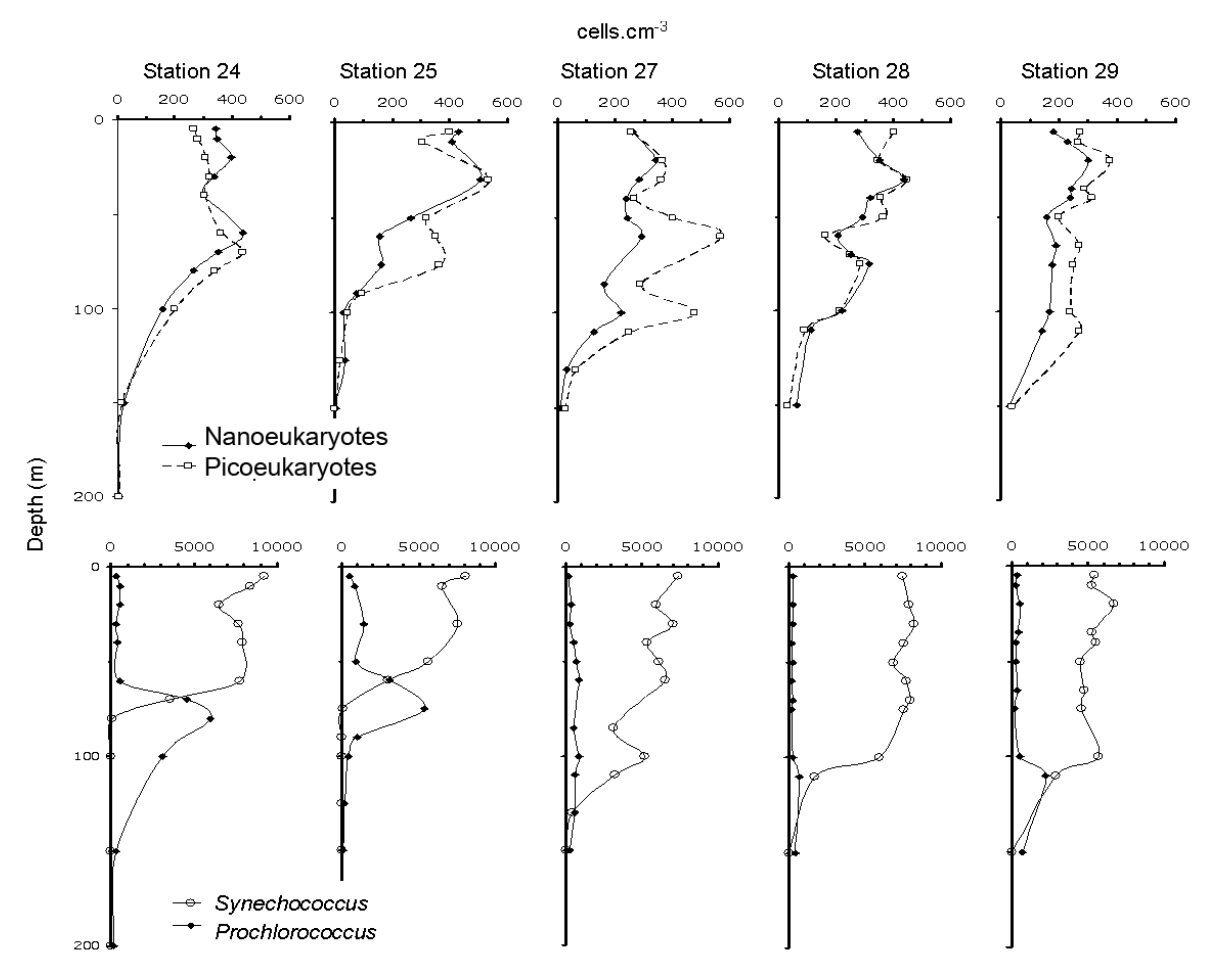

Fig. 8. Vertical profiles of ultraphytoplankton at stations 24 to 29 located along the transect crossing the thermohaline front at the eastern Ionian basin, as evidenced in Fig. 6.

Considering stations 5 and 7 as representative of both sides of the Sicily Strait, and salinity as the driving factor, we found a linear relationship between depth and the ratio $S_{7} / S_{5}$ of salinity values from the same depths at stations 5 and 7 . This relationship applies to the $75-150 \mathrm{~m}$ depth range as illustrated by Fig. 13a together with the vertical distribution of salinity at both stations in the same depth range (Fig. 13b). We also found a significant linear relationship in the same depth range between depth and the picoeukaryote abundance ratio $\mathrm{PicO}_{7} / \mathrm{PicO}_{5}$ as shown in Fig. 13c. From both relationships, we derived a significant $\left(r^{2}=0.87, p<0.05\right)$ correlation between both abundance and salinity ratios: $\mathrm{Pico}_{7} / \mathrm{Pico}_{5}=$ $a \operatorname{Ln}\left(S_{7} / S_{5}\right)+b$ (Fig. 13d). A similar relationship was significant $\left(r^{2}=0.75, p<0.05\right)$ for nanoeukaryotes but not significant for Synechococcus (Table 4). The difference in water masses is not limited to salinity. Indeed we found a linear relationship between nutrient and salinity ratios at stations 5 and 7 (Table 4).

\section{Discussion}

Phytoplankton distribution in the eastern Mediterranean Sea has been poorly documented until the recent years. Only few spatially limited investigations of ultraphytoplankton abundances corresponding to different periods were reported in the literature (Li et al., 1993; Yacobi et al., 1995; Zohary et al., 1998; Casotti et al., 2003; Psarra et al., 2005; Tanaka et al., 2007; see also the review by Siokou-Frangou et al., 2010). The only synoptic study related to phytoplankton, to our knowledge, was that derived from ocean color data (CZCS) conducted by Antoine et al. (1995) and dedicated to chlorophyll $a$ and primary production. The METEOR 31/1 cruise (January 1995) provided support for the first basinscale field-study of phytoplankton distribution in the eastern Mediterranean Sea. Thus a basin-wide winter phytoplankton pigment distribution in the eastern Mediterranean Sea, conducted during this cruise, was reported (Vidussi et al., 2001). In parallel the study presented here reports the first basinwide spatial distribution of ultraphytoplankton $(<10 \mu \mathrm{m}) \mathrm{de}-$ termined by flow cytometry. Since then, further flow cytometry studies in the eastern Mediterranean Sea at a few sites were achieved in springtime on picophytoplankton (Moutin et al., 2002) or in summer on ultraphytoplankton (Psarra et al., 2005) and on ultraphytoplankton distribution exclusively in the Ionian basin (Casotti et al., 2003).

The dominance of picoeukaryotes over nanoeukaryotes reported in this study reflects the general oligotrophic status of the eastern Mediterranean Sea even during the winter season as evidenced by the Rpn index (Denis et al., 2003). This index, which was proposed for the first time during a study on the transition from mesotrophy to oligotrophy observed in western Mediterranean Sea is defined by the abundance ratio picoeukaryotes/nanoeukaryotes and characterizes the 

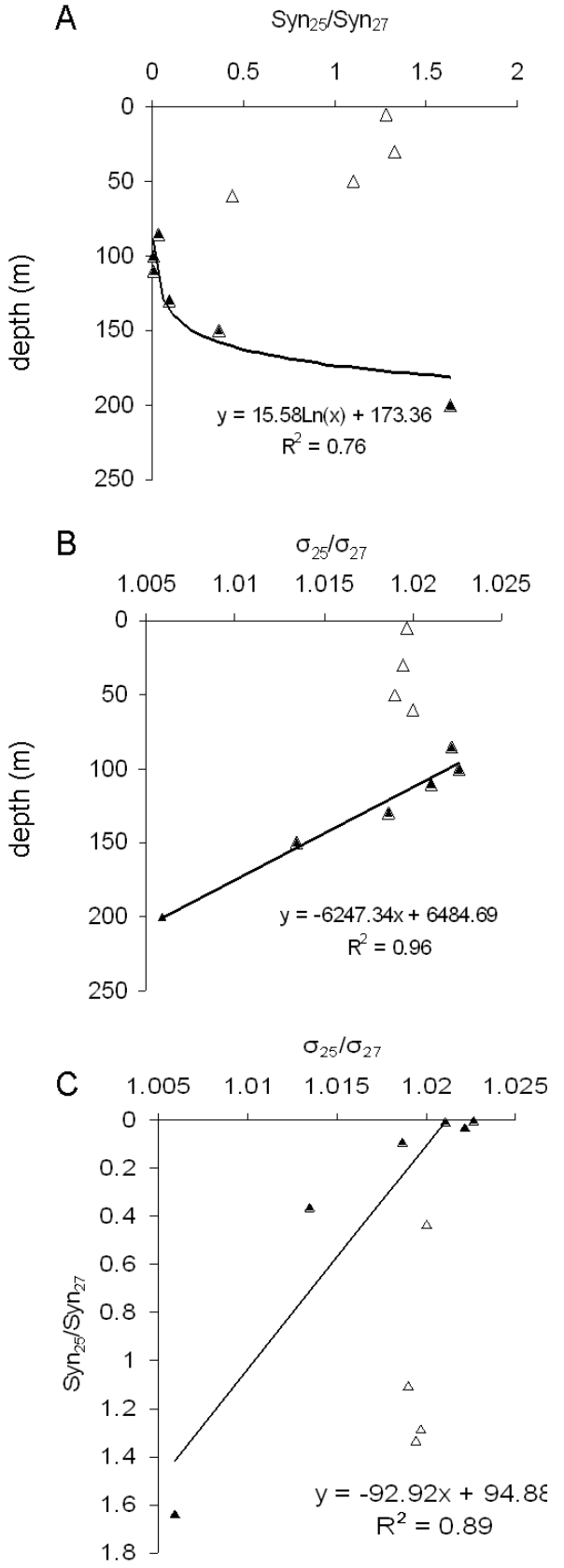

Fig. 9. Relationships between vertical distributions of Synechococcus abundance and density north (station 25) and south (station27) of the thermohaline front. (A) Depth dependence of the abundance ratio $\mathrm{Syn}_{25} / \mathrm{Syn}_{27}$. (B) Depth dependence of the density ratio $\sigma_{25} / \sigma_{27}$. (C) Relationship between Synechococcus abundance ratio $\operatorname{Syn}_{25} / \operatorname{Syn}_{27}$ and density ratio $\sigma_{25} / \sigma_{27}$.

mesotrophic $(R p n<1)$ or oligotrophic $(R p n>1)$ status of an ecosystem. The carbon biomass estimations showed that Synechococcus contributed $3.3 \%$ to $67.7 \%$ to the overall phytoplanktonic biomass in the eastern Mediterranean Sea (Table 3). In contrast, Prochlorococcus contributed far less,
R/V METEOR Cruise M31/1 (January 1995)
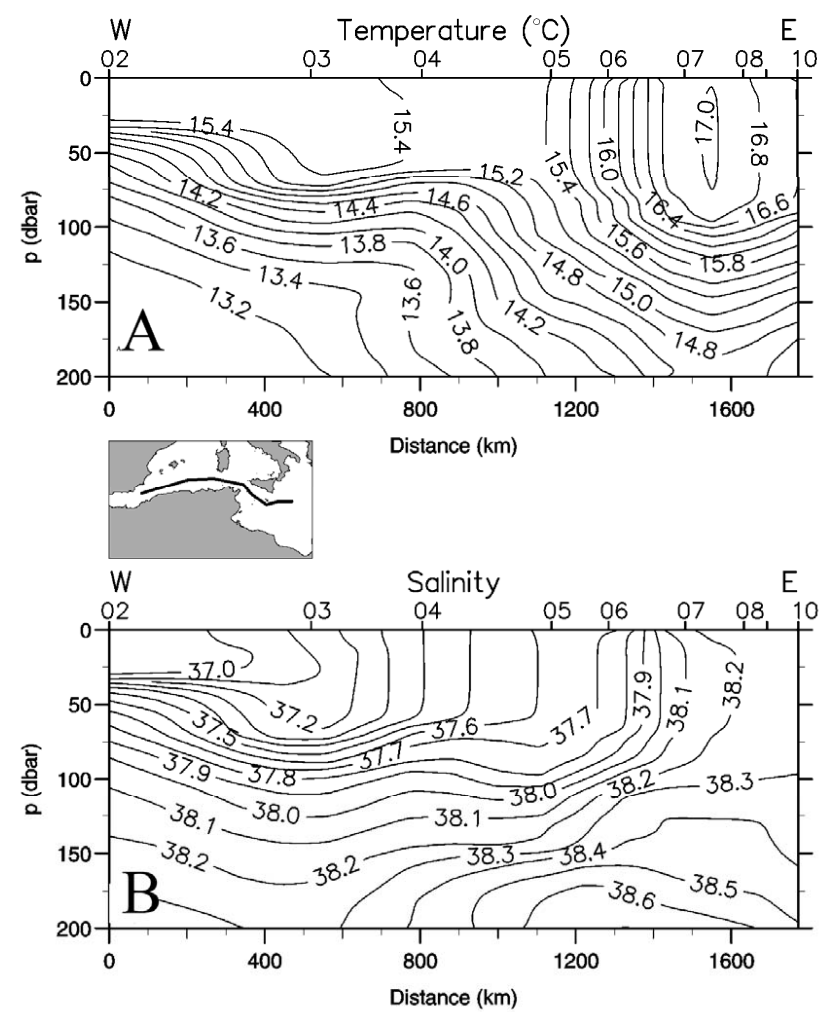

Fig. 10. Vertical distribution of (A) temperature and (B) salinity across the western Mediterranean Sea and the western part of the Ionian basin illustrating the difference in temperature and salinity on both sides of the Sicily Strait.

from $0.5 \%$ to 6.5 . Synechococcus represented more than $20 \%$ of the overall phytoplankton biomass at the majority of sampled stations. The mean integrated carbon biomasses of pico- and nanoeukaryotes (168 and $681 \mathrm{mg} \mathrm{C} \mathrm{m}^{-2}$ respectively) are in agreement with mean values derived from their integrated chl $a$ biomasses (270 and $630 \mathrm{mg} \mathrm{C} \mathrm{m}^{-2}$ respectively) as reported by Vidussi et al. (2001) when using the $\mathrm{C} / \mathrm{Chl} a$ conversion factor of 50 (Brown et al., 1999). The choice of this ratio is consistent with the ratio value of 55 obtained from data assimilation modelling in the north western Mediterranean Sea (Faugeras et al., 2003) and with the ratio value of 47 obtained from an experimental approach in the same region (Latasa et al., 2005). The spatial distribution of the four resolved ultraphytoplanktonic clusters was not uniform over the eastern Mediterranean Sea where Synechococcus was the dominant species. However, its maximum abundance (about 37000 cells $\mathrm{cm}^{-3}$ ) was $26 \%$ less than the winter maximum concentration (about 50000 cell $\mathrm{cm}^{-3}$ ) reported for the western Mediterranean Sea (Vaulot et al., 1990). In the western Mediterranean Sea, the presence of Prochlorococcus in the top layer was consistent with the observations of Vaulot et al. (1990). Contrary to other 

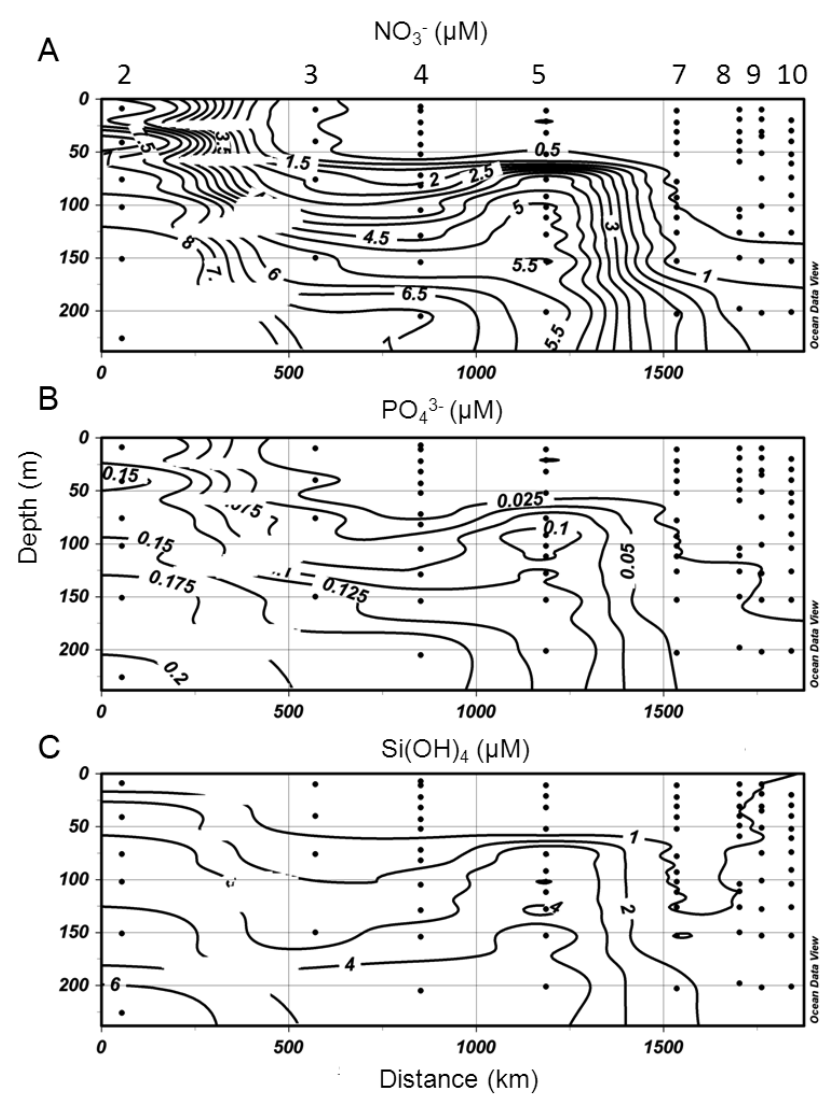

Fig. 11. Vertical distribution of (A) nitrate $\left(\mathrm{NO}^{3-}\right)$, (B) phosphate $\left(\mathrm{PO}_{4}^{3-}\right)$ and (C) Silicate $\left.\mathrm{Si}(\mathrm{OH})_{4}\right)$ down to $200 \mathrm{~m}$ across the western Mediterranean Sea and the western part of the Ionian basin.

oligotrophic ocean regions, where Prochlorococcus dominates the picophytoplankton fraction (see review of Partensky et al., 1999 and references therein), the dominance of Synechococcus during this study supports the suggestion that Synechococcus would be more adapted than Prochlorococcus to the hydrodynamical and nutrient conditions of the eastern Mediterranean Sea. Though up to now there is no direct evidence of the Mediterranean Synechococcus strain capacity for nitrogen-fixation, the recent discovery of diazotrophic unicellular cyanobacteria in the northwestern (Le Moal and Biégala, 2009) and eastern (Man-Aharonovich et al., 2007) Mediterranean Sea may suggest that Synechococcus would benefit, at least indirectly, from this nitrogen fixation. The detection of nitrogen-fixing cyanobacteria is not limited to the Mediterranean Sea. It was reported in other oligotrophic oceans (Zehr et al., 1998, 2001, 2008; Tripp et al., 2010). The winter mixing can also partly explain the dominance of Synechococcus over Prochlorococcus in the eastern Mediterranean Sea (Partensky et al., 1999). The absence of fluorescence increase with depth for Synechococcus and for the pico and nanoeukaryotic phytoplankton was reasonably due to large mixed layer depths induced by winter conditions. For instance, the mixed layer depth reached $400 \mathrm{~m}$ in the Adriatic basin. Under these conditions, Prochlorococcus mean fluorescence per cell provided evidence for the presence of two ecotypes along the water column (Martin, 1997), one occupying the upper $75 \mathrm{~m}$, the other, adapted to low light, growing preferentially below $75 \mathrm{~m}$ in agreement with previous reports (Vaulot et al., 1990; Partensky et al., 1999). A similar vertical distribution for Prochlorococcus was also reported by Tanaka et al. (2007) in the Levantine basin during the spring period. These ecotypes would also combine adaptation to the availability of nitrogen sources (nitrate, nitrite and ammonium; Moore et al., 2002). The existence of three ecotypes of Prochlorococcus was reported in equatorial Pacific (Mackey et al., 2002), however no evidence for a third species could be derived from our data. In contrast, only two ecotypes were recently identified in the Strait of Sicily, in summer (Brunet et al., 2007).

This study provides clear examples of the dependence of ultraphytoplankton spatial distribution on meso or sub-meso scale hydrodynamic features like gyres and thermohaline fronts that generate distinct water masses. In the Adriatic basin, the inside waters of the observed cyclonic gyre were very homogeneous in the upper $200 \mathrm{~m}$ in contrast with outside waters (Fig. 4a), and their ultraphytoplankton content was significantly lower than at the edge of the gyre or in surrounding waters (Fig. 4b). Synechococcus distribution was the most affected by the presence of the gyre. The linear relationships found between Synechococcus abundance and density inside and outside the gyre, express a tight control of Synechococcus by the density, at least in the depth range between 50 and $150 \mathrm{~m}$ (Fig. 5c). In the upper layer, additional factors such as light, predation and nutrients would contribute to a more complex relationship between Synechococcus abundances inside and outside the gyre.

In the Ionian basin, the presence of a thermohaline front (Fig. 6) mainly modified the vertical distribution of both Synechococcus and Prochlorococcus. North of the front, where waters were colder and more saline than south of the front, both genera appeared complementary with Synechococcus restricted to the upper $75 \mathrm{~m}$ and Prochlorococcus being as abundant below (Fig. 8). South of the front, Prochlorococcus abundance dropped to its background level below $75 \mathrm{~m}$ and was replaced by Synechococcus. The thermohaline front was also responsible for the density variations between stations 25 and 27 (Fig. 6). The large density change between 60 and $75 \mathrm{~m}$ depth at station 25 was coupled to a large drop in Synechococcus concentration (Fig. 8). In contrast, at station 27 , the vertical variation of density was less pronounced and the Synechococcus concentration decreased more progressively. Below $50 \mathrm{~m}$ depth, the ratios of cell concentrations and density between stations 25 and 27 provide evidence of a phasing in the concentration decrease with depth and of a pycnocline (ratio tending towards 1), expressing the impact of the front (Fig. 9). Both ratios were found significantly correlated (Fig. 9c). Ultraphytoplankton concentrations were larger above the pycnocline than below 

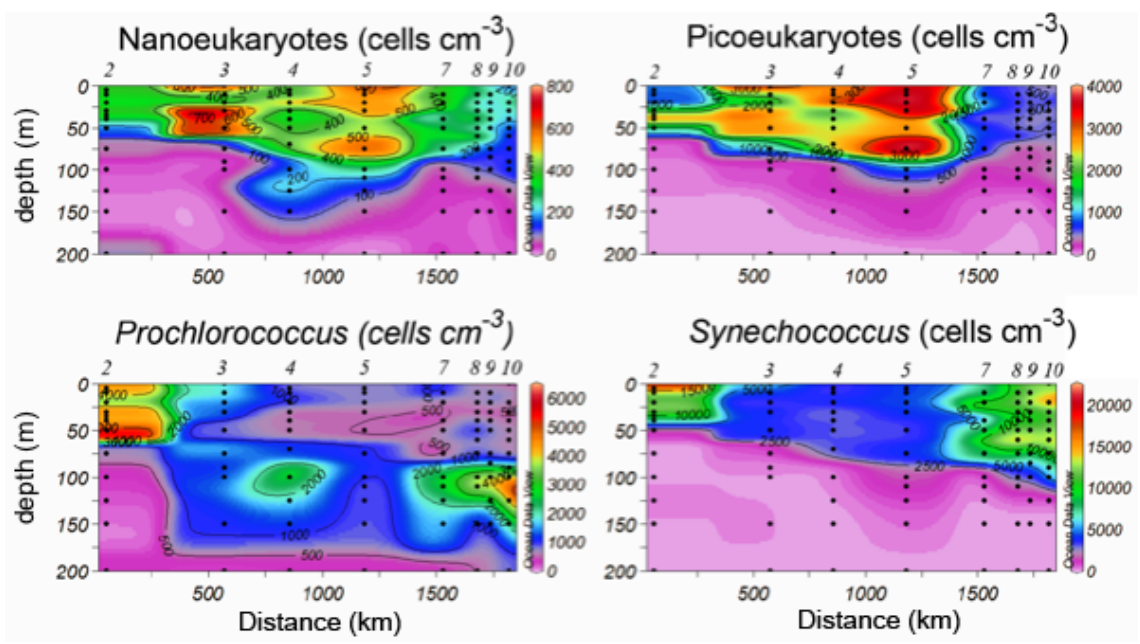

Fig. 12. Vertical distribution of ultraphytoplankton along the transect defined by stations 2 to 10 , namely nanoeukaryotes, picoeukaryotes, Prochlorococcus and Synechococcus. Note that station 5 (Sicily Strait) delimits a clear transition for all distributions between the western and eastern Mediterranean basins.

whereas density became rapidly homogeneous below the pycnocline.

In the comparison of western and eastern Mediterranean Sea, the considered changes are related to salinity, not to a local hydrodynamic system. Though salinity explains the variations in picophytoplankton distributions (Fig. 13) according to relationships analogous to those found for the frontal system in the Ionian basin, the interpretation might not be as straightforward due to the large space scale covered.

Previous studies on combined effects of hydrodynamism and nutrients in the eastern Mediterranean Sea were essentially focussed on a single structure like a warm core eddy (Krom et al., 1992, 1993). In the present study, we addressed a larger scale. Nutrient concentrations were strongly negatively correlated to all the phytoplankton groups, on a global point of view as well as on a "station by station" point of view (data not shown). This is linked to the increase of nutrient concentrations with depth, and the inherent decrease of light-dependent cell abundances. The expected relationship between the mesotrophic Mediterranean western part and the oligotrophic eastern part was not evidenced in this study. By correlating nutrients with abundances over the upper $50 \mathrm{~m}$ of the water column, no positive correlation was found ever. In such a large scale study, the lack of positive correlation between nutrients and phytoplankton can be expected, since such a relationship is strongly time dependent, and since winter phytoplankton development does not proceed with high growth rates, but faces strong nutrient needs and inter-specific competition. However, within the selected hydrographic areas of this study and below $50 \mathrm{~m}$ depth, nutrient ratios between particular stations (Table 4) were correlated to corresponding density ratios, which also were strongly correlated to the corresponding phytoplankton ratios.
A

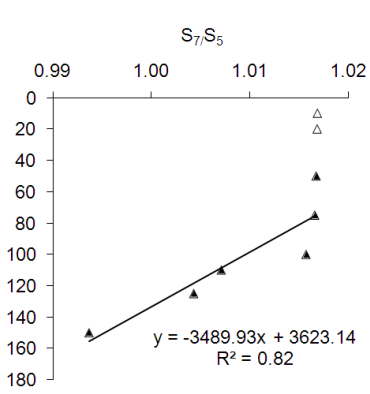

C

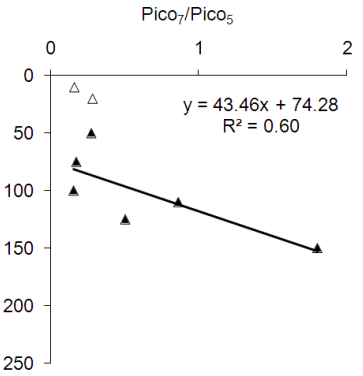

B
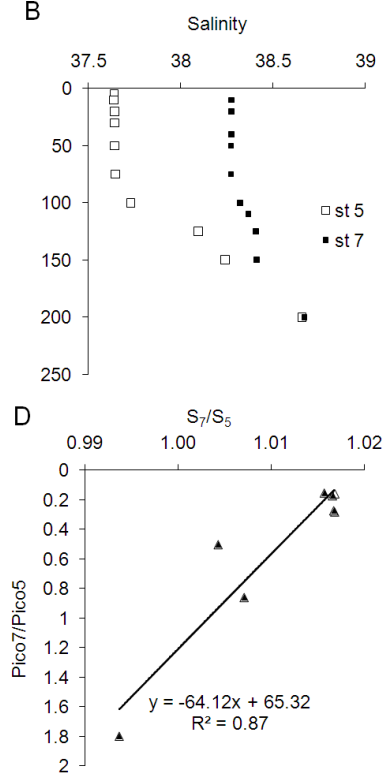

Fig. 13. Relationships between vertical distributions of picoeukaryote (Pico) abundance and salinity in the western (station 5) and eastern (station7) Mediterranean Sea. (A) Depth dependence of the salinity ratio $S_{7} / S_{5}$. (B) Vertical distribution of salinity. (C) Depth dependence of the abundance ratio $\mathrm{Pico}_{7} / \mathrm{Pico}_{5}$. (D) Relationship between picoeukaryote abundance ratio $\mathrm{Pico}_{7} / \mathrm{Pico}_{5}$ and salinity ratio $\mathrm{S}_{7} / \mathrm{S}_{5}$.

In addition to providing a basin scale distribution of ultraphytoplankton in the eastern Mediterranean Sea this study, as a main conclusion, shows that the large-scale phytoplankton distribution below $50 \mathrm{~m}$ in the considered main hydrographic structures appears to be specifically affected by hydrodynamism. 


\section{Supplementary material related to this article is available online at: http://www.biogeosciences.net/7/2227/2010/ bg-7-2227-2010-supplement.pdf.}

Acknowledgements. This work was partially supported by the CNRS-INSU and the GEODYME project (contract No. 930061 of the MTP-MAST II programme). We thank the captain and crew of the R. V. Meteor for their efficient assistance at sea. W. Roether is especially acknowledged for the opportunity of taking part to the Meteor 31 cruise. We are very grateful to J. P. Béthoux, coordinator of the GEODYME project, for his stimulating support during this study. The publication of this article is financed by CNRS-INSU.

Edited by: M. Dai

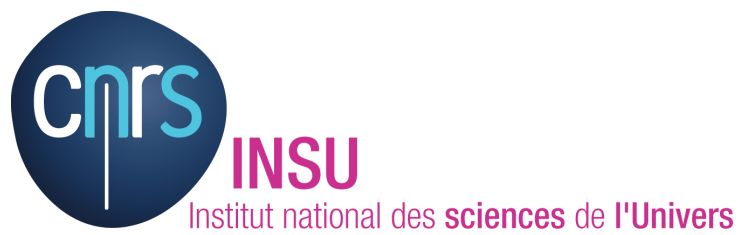

The publication of this article is financed by CNRS-INSU.

\section{References}

Antoine, D., Morel, A., and André, J.-M.: Algal pigment distribution and primary production in the eastern Mediterranean Sea as derived from coastal zone color scanner observations, J. Geophys. Res., 100(C8), 16193-16209, 1995.

Artegiani, A., Bregant, D., Paschini, E., Pinardi, N., Raicich, F., and Russo, A.: The Adriatic Sea general circulation. Part II: baroclinic circulation structure, J. Phys. Oceanogr., 27, 1515-1532, 1997.

Azov, Y.: Seasonal patterns of phytoplankton productivity and abundance in nearshore oligotrophic waters of Levant Basin (Mediterranean), J. Plankton Res., 8, 41-53, 1986.

Berland, B.: Azote ou phosphore ? Considérations sur le " paradoxe nutritionnel " de la mer Méditerranée, Oceanol. Acta, 3, 135$142,1980$.

Berman, T., Townsend, D. W., El-Sayed, S. Z., Trees, C. C., and Azov, Y.: Optical transparency, chlorophyll and primary productivity in the eastern Mediterranean near the Israeli coast, Oceanol. Acta, 7, 367-372, 1984.

Bonin, D. J., Bonin, M. C., and Berman, T.: Mise en évidence expérimentale des facteurs nutritifs limitants de la production du micro-nanoplancton et de l'ultraplancton dans une eau côtière de la Méditerranée orientale (Haïfa, Israël), Aquat. Sci., 51, 129 152,1989

Brown, S. L., Landry, M. R., Barber, R. T., Campbell, L., Garrison D. L., and Gowing, M. M.: Picophytoplankton dynamics and production in the Arabian Sea during the 1995 southwest monsoon, Deep-Sea Res. II, 46, 1745-1768, 1999.

Brunet, C., Casotti, R., Vantrepotte, V., and Conversano, F.: Vertical variability and diel dynamics of picophytoplankton in the Strait of Sicily, Mediterranean Sea, in summer, Mar. Ecol. Prog. Ser. 346, 15-26, 2007.

Cailliau, C., Claustre, H., Vidussi, F., Marie, D., and Vaulot, D.: Carbon biomass, and gross growth rates as estimated from 14C pigment labelling, during photoacclimatation in Prochlorococcus CCMP 1378, Mar. Ecol. Prog. Ser., 145, 209-211, 1996.

Carter, E. F. and Robinson, A. R.: Analysis models for estimation of ocean fields, J. Atmos. Ocean Tech., 4(1), 49-74, 1987.

Casotti, R., Landolfi, A., Brunet, C., D’Ortenzio, F., Mangoni, O., Ribera d'Alcalà, M., and Denis, M.: Composition and dynamics of the phytoplankton of the Ionian Sea (eastern Mediterranean), J. Geophys. Res., 108, 8116, doi:10.1029/2002JC001541, 2003.

Claustre, H., Kerhervé, P., Marty, J.-C., Prieur, L., Videau, C., and Hecq, J.-H. : Phytoplankton dynamics associated with a geostrophic front : ecological and biogeochemical implications, J. Mar. Res., 52, 711-742, 1994.

Conan, P., Pujo-Pay, M., Raimbault, P., and Leveau, M.: Variabilité hydrologique et biologique du golfe du Lion. II. Productivité sur le bord interne du courant,Oceanol. Acta, 21, 767-782, 1998.

Denis, M., Martin V., and Andersen, V.: Short-term variations of the vertical distribution of cyanobacteria in the open Mediterranean Sea, Sci. Mar., 64, 157-163, 2000.

Denis, M., Martin, V., Momzikoff, A., Gondry, G., Stemmann, L., Demers, S., Gorsky, G., and Andersen, V.: Pulsed remineralisation in the north western Mediterranean Sea: an hypothesis, J. Mar. Syst., 39, 19-41, 2003.

Faugeras, B., Lévy, M., Mémery, L., Verron, J., Blum, J., and Charpentier, I.: Can biogeochemical fluxes be recovered from nitrate and chlorophyll data? A case study assimilating data in the north western Mediterranean Sea at the JGOFS-DYFAMED station, J. Mar. Syst., 40-41, 99-125, 2003.

Gacic, M., Kovacevich, V., Manca, B., Papageorgiou, E., Poulain, P. M., Scarazzato, P., and Vetrano, A.: Thermohaline properties and circulation in the Strait of Otranto. In: F. Briand (Editor), Dynamics of Mediterranean Straits and Channels. Bul. Inst. Oceanogr., Special Issue, 17, CIESM Science Series, 2, 117$145,1996$.

Grasshoff, K., Ehrhardt, M., Kremling, K., and Almgren, T.: Methods of Seawater Analysis, Verlag Chemie, Weinheim, Germany, 632 pp., 1983.

Krom, M. D., Kress, N., Brenner, S., and Gordon, L. I.: Phosphorus limitation of primary productivity in the eastern Mediterranean, Limnol. Oceanogr., 36, 424-432, 1991.

Krom, M. D., Brenner, S., Kress, N., Neori, A., and Gordon, L. I.: Nutrient dynamics and new production in a warm-core eddy from the eastern Mediterranean Sea, Deep-Sea Res., 39, 467480, 1992.

Krom, M. D., Brenner, S., Kress, N., Neori, A., and Gordon, L. I.: Nutrient distributions during an annual cycle across a warm-core eddy from the E. Mediterranean Sea, Deep-Sea Res., 40, 805$825,1993$.

Krom, M. D., Groom, S., and Zohary, T.: The eastern Mediterranean, in : The Biogeochemistry of Marine Systems, edited by: Black, K. D. and Shimmield, G. B., Blackwell Publishing Oxford, 91-126, 2003.

Krom, M. D., Thingstad, T. F., Brenner, S., Carbo, P., Drakopoulos, P., Fileman, T. W., Flaten, G. A. F., Groom, S., Herut, B., Kitidis, V., Kress, N., Law, C. S., Liddicoat, M. I., Mantoura, R. F. C., Pasternak, A., Pitta, P., Polychronaki, T., Psarra, S., Rassoulzade- 
gan, F., Skjoldal, E. F., Spyres, G., Tanaka, T., Tselepides, A., Wassmann, P., Wexels Riser, C., Woodward, E. M. S., Zodiatis, G., and Zohary, T.: Summary and overview of the CYCLOPS $P$ addition Lagrangian experiment in the eastern Mediterranean, Deep-Sea Res. II, 52, 3090-3108, 2005.

Leaman, K. D. and Schott, F. A.: Hydrographic structure of the convection regime in the Gulf of Lions: Winter 1987, J. Phys. Oceanogr., 21, 575-598, 1991.

Le Moal, M. and Biégala I.: Diazotrophic unicellular cyanobacteria in the northern Mediterranean Sea : a seasonal Cycle, Limnol. Oceanogr., 54, 845-855, 2009.

Li, W. K. W., Zohary, T., Yacobi, Y. Z., and Wood, A. M.: Ultraphytoplankton in the eastern Mediterranean Sea: towards deriving phytoplankton biomass from flow cytometric measurements of abundance, fluorescence and light scatter, Mar. Ecol. Prog. Ser., 102, 79-87, 1993.

LIWEX, Group: The Levantine Intermediate Water Experiment (LIWEX) Group: Levantine basin - A laboratory for multiple water mass formation processes, J. Geophys. Res., 108(1), 8101, doi:10.1029/2002JC001643, 2003.

Mackey, D. J., Blanchot, J., Higgins, H. W., and Neveux, J.: Phytoplankton abundances and community structure in the equatorial Pacific, Deep-Sea Res. II, 49, 2561-2582, 2002.

Magazzù, G. and Decembrini, F.: Primary production, biomass and abundance of phototrophic picoplankton in the Mediterranean Sea: a review, Aquat. Microb. Ecol., 9, 97-104, 1995.

Malanotte-Rizzoli, P., Manca, B. B., Ribera d'Alcalà, M., Theocharis, A., Brenner, S., Budillon, G., and Ozsoy, E.: The eastern Mediterranean in the 80s and in the 90s: the big transition in the intermediate and deep circulations, Dyn. Atmos. Oceans, 29, 365-395, 1999.

Man-Aharonovich, D., Kress, N., Bar Zeev, E., Berman-Frank, I., and Béjà, O.: Molecular ecology of nifH genes and transcripts in th eeastern Mediterranean Sea, Environ. Microbiol., 9, 23542363, 2007.

Martin, V.: Etude par cytométrie en flux de la distribution des populations phytoplanctoniques en Méditerranée. Mise en relation avec la production métabolique de $\mathrm{CO} 2$ et comparaison avec le Golfe du Saint Laurent, Thesis, Université de la Méditerranée, 250 pp., 1997.

Marty, J.-C., Chiavérini, J., Pizay, M.-D., and Avril, B.: Seasonal ad interannual dynamics of nutrients and phytoplankton pigments in the western Mediterranean Sea at the DYFAMED time-series station (1991-1999), Deep-Sea Res. II, 49, 1965-1985, 2002.

McGillicuddy, D. J., Robinson, A. R., Siegel, D. A., Jannasch, H. W., Johnson, R., Dickey, T. D., McNeil, J., Michaels, A. F., and Knap, A. H.: Influence of mesoscale eddies on new production in the Sargasso Sea, Nature, 394, 263-265, 1998.

Minas, H. J., Minas, M., Coste, B., Gostan, J., Nival, P., and Bonin, M.-C.: Production de base et de recyclage; une revue de la problématique en Méditerranée nord-occidentale, In: Oceanol. Acta, Océanologie pélagique méditerranéenne, edited by: Minas, H. J. and Nival, P., 155-162, 1988.

Moore, L. R., Post, A. F., Rocab, G., and Chisholm, S. W.: Utilization of different nitrogen sources by marine cyanobacteria Prochlorococcus and Synechococcus, Limnol. Oceanogr., 47, 989-996, 2002.

Moutin, T., Thingstad, T. F., Van Wambeke, F., Marie, D., Slawyk, G., Raimbault, P., and Claustre, H.: Does competition for nano-molar phosphate supply explain the predominance of the cyanobacterium Synechococcus?, Limnol. Oceanogr., 47, 1562$1567,2002$.

Ovchinnikov, I. M., Zats, V. I., Krivosheya, V. G., and Udodov, A. I.: Formation of deep Eastern Mediterranean waters in the Adriatic Sea, Oceanol. Acad. Sci. USSR., 25, 911-917, 1985.

Partensky, F., Hess, W. R., and Vaulot, D.: Prochlorococcus, a marine photosynthetic prokaryote of global significance, Microbiol. Mol. Biol. Rev., 63, 106-127, 1999.

Platt, T., Subba Rao, D. V., and Irvin, B.: Photosynthesis of picoplankton in the oligotrophic ocean, Nature, 301, 702-704, 1983.

POEM group: The general circulation of the eastern Mediterranean, Earth Sci. Rev., 32, 285-309, 1992.

Psarra, S., Tselepides, A., and Ignatiades L.: Primary productivity in the Cretan Sea (NE Mediterranean):seasonal and interannual variability, Prog. Oceanogr., 46,187-204, 2000.

Psarra, S., Zohary, T., Krom, M. D., Mantoura, R. F. C., Polychronaki, T., Stambler, N., Tanaka, T., Tselepides, A., and Thingstad, T. F.: Phytoplankton response to a Lagrangian phosphate addition in the Levantine Sea (eastern Mediterranean), Deep-Sea Res. II, 52, 2944-2960, 2005.

Rodriguez, J., Tintore, J., Allen, J. T., Blanco, J. M., Gomis, D., Reul, A., Ruiz, J., Rodriguez, V., Echevarria, F., and Rodriguez, F. J.: Mesoscale vertical motion and the size structure of phytoplankton in the ocean, Nature, 410, 360-363, 2001.

Roussenov, V., Stanev, E., Artale, V., and Pinardi, N.: A seasonal model of the Mediterranean Sea general circulation, J. Geophys. Res., 100, 13515-13538, 1995.

Schlitzer, R.: Ocean Data view, available online at: http://www. awibremerhaven.de/GEO/ODV, 2002.

Schlitzer, R., Roether, W., Oster, H., Junghans, H.-G., Hausmann, M., Johannsen, H., and Michelato, A.: Chlorofluoromethane and oxygen in the eastern Mediterranean, Deep-Sea Res., 38, 1531$1551,1991$.

Siokou-Frangou, I., Christaki, U., Mazzocchi, M. G., Montresor, M., Ribera d'Alcalá, M., Vaqué, D., and Zingone, A.: Plankton in the open Mediterranean Sea: a review, Biogeosciences, 7, 1543-1586, doi:10.5194/bg-7-1543-2010, 2010.

Tanaka, T., Zohary, T., Krom, M. D.,Law, C. S., Pitta, P., Psarra, P., Rassoulzadegan, F., Thingstad, T. F., Tselepides, A., Woodward, E. M. S., Fonnes Flaten, G. A., Skjoldal, E. F., and Zodiatis, G.: Microbial community structure and function in the Levantine Basin of the Mediterranean, Deep-Sea Res., 54, 1721-1743, 2007.

Thingstad, T. F., Krom, M. D., Mantoura, R. F. C., Flaten, G. A. F., Groom, S., Herut, B., Kress, N., Law, C. S., Pasternak, A., Pitta, P., Psarra, S., Rassoulzadegan F., Tanaka, T., Tselepides, A., Wassmann, P. Woodward, E. M. S., Wexels Riser, C., Zodiatis, G., and Zohary, T.: Nature of phosphorus limitation in the ultraoligotrophic eastern Mediterranean, Science, 309, 1068 1071, 2005.

Tripp, H. J., Bench, S. R., Turk, K. A., Foster, R. A., Desany, B. A., Niazi, F., Affourtit, J. P., and Zehr, J. P.: Mataboloic streamlining in an open-ocean nitrogen-fixing cyanobacterium, Nature, 464, 90-94, 2010.

Trousselier, M., Courties, C., and Zettlemaier, S.: Flow cytometric analysis of coastal lagoon bacterioplankton and picoplankton : fixation and storage effects, Estuar. Coast. Shelf Res., 40, 621- 
623, 1995.

Tselepides, A., Zervakis, V., Polychronaki, T., Donavaro, R., and Chronis, G.: Distribution of nutrients and particulate organic matter in relation to the prevailing hydrographic features of the Cretan Sea (NE Mediterranean), Prog. Oceanogr., 46, 113-142, 2000.

Van Wambeke, F., Christaki, U., Giannakourou, A., Moutin, T., and Souvemerzoglou, K.: Longitudinal and vertical trends of bacterial limitation by phosphorus and carbon in the Mediterranean Sea, Microb. Ecol., 43, 119-133, 2002.

Vaulot, D., Courties, C., and Partensky, F.: A simple method to preserve oceanic phytoplankton for flow cytometric analyses, $\mathrm{Cy}$ tometry, 10, 629-635, 1989.

Vaulot, D., Partensky, F., Neveux, J., Mantoura, R. F. C., and Llewellyn, C. A.: Winter presence of prochlorophytes in surface waters of the north western Mediterranean Sea, Limnol. Oceanogr., 35, 1156-1164, 1990.

Vaulot, D., LeBot, N., Marie, D., and Fukai, E.: Effect of phosphorus on the Synechococcus cell cycle in surface Mediterranean waters during summer, Appl. Environ. Microbiol., 62, 2527-2533, 1996.

Verity, P. G., Robertson, C. Y., Tronzo, C. R., Andrews, M. G., Nelson, J. R., and Sieracki, M. E.: Relationships between cell volume and the carbon and nitrogen content of marine photosynthetic nanoplankton, Limnol. Oceanogr., 37, 1434-1446, 1992.

Vidussi, F., Claustre, H., Bustillo-Guzman, J., Caillau, C., and Marty, J.-C.: Determination of chlorophylls and carotenoids of marine phytoplankton. Separation of chlorophyll $a$ from divinylchlorophyll $a$ and zeaxanthin from lutein, J. Plankt. Res., 18, 2377-2382, 1996.

Vidussi, F., Claustre, H., Manca, B. B., Luchetta, A., and Marty, J.-C.: Phytoplankton pigment distribution in relation to upper thermocline circulation in the eastern Mediterranean Sea during winter, J. Geophys. Res., 106(C9), 19939-19956, 2001.
Waterbury, J. B., Watson, S. W., Valois, F. W., and Franks, D. G.: Biological and ecological characterization of the marine unicellular cyanobacterium Synechococcus, in: Photosynthetic picoplankton, edited by: Platt, T. and Li, W. K. W., Can. Bul. Fish. Aquat. Sci., 71-120, 1986.

Yacobi, Y. Z., Zohary, T., Kress, N., Hecht, A., Robarts, R. D., Waiser, M., Wood, W., and Li, W. K. W.: Chlorophyll distribution throughout the southeastern Mediterranean in relation to the physical structure of water mass, J. Mar. Syst., 6, 179-190, 1995.

Zehr, J. P., Mellon, M. T., and Zani, S.: New nitrogen-fixing microorganisms detected in oligotrophic oceans by amplification of nitrogenase (nifH) genes, Appl. Environ. Microbiol., 64, 34443450, 1998.

Zehr, J. P., Waterbury, J. B., Turner, P. J., Montoya, J. P., Omoregie, E., Steward, G. F., Hansen, A., and Karl, D. M.: Unicellular cyanobacteria fix N2 in the subtropical north Pacific Ocean, Nature, 412, 635-638, 2001.

Zehr, J. P., Bench, S. R., Carter, J. B., Hewson, I., Niazi, F., Shi, T., Tripp, H. J., and Affourtit, J. P.: Globally distributed uncultivated oceanic $\mathrm{N}_{2}$-fixing cyanobacteria lack oxygenic photosystem II, Science, 322, 1110-1112, 2008.

Zohary, T., Brenner, S., Krom, M. D., Angel, D. L., Kress, N., Li, W. K. W., Neori, A., and Yacobi, Y. Z.: Buildup of microbial biomass during deep winter mixing in a Mediterranean warmcore eddy, Mar. Ecol. Prog. Ser., 167, 47-57, 1998.

Zohary, T. and Robarts, R. D.: Experimental study of microbial Plimitation in the eastern Mediterranean, Limnol. Oceanogr., 43, 387-395, 1998.

Zohary, T., Herut, B., Krom, M. D., Fauzi, R., Mantoura, C., Pitta, P., Psarra, S., Rassoulzadegan, F., Stambler, N., Tanaka, T., Thingstad, T. F., and Woodward, E. M. S.: P-limited bacteria but $\mathrm{N}$ and $\mathrm{P}$ co-limited phytoplankton in the eastern Mediterranean - a microcosm experiment, Deep-Sea Res. II, 52, 3011-3023, 2005. 